\title{
Article \\ A Late Holocene Stable Isotope and Carbon Accumulation Record from Teringi Bog in Southern Estonia
}

\author{
Nathan D. Stansell ${ }^{1, *}$, Eric S. Klein ${ }^{2}$, Kristyn Hill $^{1}$, Jaanus Terasmaa ${ }^{3} \oplus$, Justin Dodd ${ }^{1} \oplus$, Maxwell Boes ${ }^{1}$, \\ Mariliis Eensalu ${ }^{1}$, Carolyn Fortney ${ }^{1}$, Annabella Fritts ${ }^{4}{ }^{5}$, Roxana Garcia ${ }^{6}$, Brittany Price ${ }^{1}$ and Brandy Swanson ${ }^{7}$
}

1 Department of Geology and Environmental Geosciences, Northern Illinois University, 312 Davis Hall, Normal Road, DeKalb, IL 60115, USA; hill.kristyn6@gmail.com (K.H.); jdodd@niu.edu (J.D.); Z1799416@students.niu.edu (M.B.); Z1863301@students.niu.edu (M.E.); cafortney91@gmail.com (C.F.); Z1852120@students.niu.edu (B.P.)

2 Department of Geological Sciences, University of Alaska Anchorage, 3211 Providence Drive, Anchorage, AK 99508, USA; esklein@alaska.edu

3 Institute of Ecology, Tallinn University, Uus-Sadama 5, 10120 Tallinn, Estonia; jaanus.terasmaa@tlu.ee

4 Department of Earth and Environmental Sciences, University of Michigan, Earth and Environmental Sciences, Ann Arbor, MI 48109, USA; acfritts@umich.edu

5 Triton College, Chicago, IL 60171, USA

6 Waubonsee Community College, Sugar Grove, IL 60554, USA; rgarcia4@student.waubonsee.edu

7 Huntley High School, Huntley, IL 60142, USA; bswanson@district158.org

* Correspondence: nstansell@niu.edu

check for updates

Citation: Stansell, N.D.; Klein, E.S.; Hill, K.; Terasmaa, J.; Dodd, J.; Boes, M.; Eensalu, M.; Fortney, C.; Fritts, A.; Garcia, R.; et al. A Late Holocene Stable Isotope and Carbon Accumulation Record from Teringi Bog in Southern Estonia. Quaternary 2022, 5, 8. https://doi.org/10.3390/ quat5010008

Academic Editor: Ioannis Liritzis

Received: 17 August 2021

Accepted: 4 January 2022

Published: 1 February 2022

Publisher's Note: MDPI stays neutral with regard to jurisdictional claims in published maps and institutional affiliations.

Copyright: () 2022 by the authors. Licensee MDPI, Basel, Switzerland. This article is an open access article distributed under the terms and conditions of the Creative Commons Attribution (CC BY) license (https:// creativecommons.org/licenses/by/ $4.0 /)$.

\begin{abstract}
Radiocarbon-dated peat cores collected from an ombrotrophic bog in southern Estonia record shifting environmental conditions and carbon accumulation rates in northern Europe during the late Holocene. Modern observations indicate that the water balance of the peatland is highly influenced by changes in relative humidity, followed by temperature and precipitation. The modern $\delta^{18} \mathrm{O}$ and $\delta^{2} \mathrm{H}$ values of surface water suggest that the groundwater is an integration of several months of precipitation. There also appears to be little or no direct influence of surface evaporation on the water within the bog, suggesting that water loss is preferentially through transpiration and sub-surface flow. Bulk peat $\delta^{13} \mathrm{C}$ values exhibit a trend of higher values through the late Holocene, suggesting a pattern of overall increased surface wetness. The $\delta^{15} \mathrm{~N}$ values were low from $\sim 4130$ to $3645 \mathrm{cal}$ yr BP, suggesting drier conditions, followed by intermediate values until $2995 \mathrm{cal}$ yr BP. The $\delta^{15} \mathrm{~N}$ values decrease again from $\sim 2995$ to 2470 cal yr BP, suggesting a return to drier conditions, followed by intermediate values until $\sim 955 \mathrm{cal}$ yr BP. The $\delta^{15} \mathrm{~N}$ values were high, suggesting wetter conditions from $\sim 955$ to $250 \mathrm{cal}$ yr BP, followed by intermediate values through the modern. Carbon accumulation rates were low to intermediate from $\sim 4200$ to 2470 cal yr BP, followed by intermediateto-high values until $\sim 1645 \mathrm{cal}$ yr BP. Carbon accumulation rates were then low until $\sim 585 \mathrm{cal}$ yr BP, followed by intermediate values through the modern. The geochemical data, combined with observed changes in peat composition and regional proxies of temperature and water table fluctuations through the late Holocene, suggest that carbon accumulation rates were relatively low under dry and warm conditions, whereas accumulation was generally higher (up to $\sim 80 \mathrm{~g} \mathrm{C} \mathrm{m}^{-2} \mathrm{yr}^{-1}$ ) when the climate was wetter and/or colder. These findings further suggest that future environmental changes affecting the regional water balance and temperature will impact the potential for northern peatlands to capture and store carbon.
\end{abstract}

Keywords: northern Europe; Baltic region; carbon and nitrogen isotopes; C:N; carbon dynamics; water isotopes

\section{Introduction}

Peatlands are an integral part of the global carbon cycle, and they are sensitive to changing environmental conditions. High northern latitude peatlands cover approximately 
4 million $\mathrm{km}^{2}$ and store up to $550 \mathrm{Pg}\left(1 \mathrm{Pg}=10^{15} \mathrm{~g}\right)$ of carbon [1-3], equivalent to almost one-third of the world's soil carbon [4], and more than half of today's atmospheric $\mathrm{CO}_{2}$ [5]. Nevertheless, it is unclear how this internationally important carbon reservoir responds to specific climate forcings and how these responses will drive ecosystem-climate feedbacks [6-9]. Previous studies highlight the impacts of climate change on peatland carbon dynamics at a large scale [10]; however, the local- and regional-scale responses of peatland hydrology and carbon accumulation to environmental changes need to be better evaluated to improve dynamic modeling of peat accumulation through time [11].

The ecological and biological characteristics of peatlands are largely governed by hydrological conditions. For example, the trophic status of a peatland is classified principally on hydrologic regime, and the height of the water table is the primary delineating factor separating physical and chemical processes in these systems [12]; the depth of the water table separates the acrotelm with oxic conditions (above) from the catotelm with anoxic conditions (below). Recent studies suggest that there is an intermediate zone, the mesotelm [13], where the fluctuating water table causes variations in redox conditions that likely increase carbon turn over [14]. As such, any process that affects water table conditions has the potential to drive environmental responses in these highly sensitive ecosystems. In ombrotrophic systems, these processes should be dominated by changes in humidity, temperature, precipitation amounts, and residence times of water flowing through peat. The oxygen isotopic composition of precipitation $\left({ }^{18} \mathrm{O}_{p}\right)$ of Estonian surface water tracks these environmental changes [15-19], and in turn, provides insight into the modern hydrologic processes operating in bog systems. From a paleo-perspective, carbon and nitrogen isotopes $\left(\delta^{13} \mathrm{C}\right.$ and $\left.\delta^{15} \mathrm{~N}\right)$ serve as proxies of surface wetness [15] and connectedness to the water table [16].

Ultimately, the carbon balance of peatlands is related to productivity, respiration, and decomposition. Whether a peatland will be a source or a sink of greenhouse gases is also closely related to the hydrologic dynamics described above because the position of the water table determines the boundary between aerobic and anaerobic microbial respiration. Both biotic production and peat decomposition rates in peatlands are controlled largely by water availability and temperature [1]. Most newly formed biomass is subsequently decomposed by aerobic decay and then respired. As plant litter transitions into the anaerobic catotelm, some is decomposed to $\mathrm{CO}_{2}$ and $\mathrm{CH}_{4}$, while the rest is disconnected from atmospheric exchanges and stored as peat. Much of the $\mathrm{CO}_{2}$ and $\mathrm{CH}_{4}$ is lost at the surface through diffusion, bubbling, or stem and root aerenchyma [12]. Therefore, depending on hydrologic conditions, peatlands serve as both sinks and sources of $\mathrm{CO}_{2}$ and $\mathrm{CH}_{4}[3,17]$, and the fate of the stored fraction of this carbon has important consequences for global climate feedbacks $[10,18-20]$.

Here, we present a $\sim 4200$-year-old stable isotope $\left(\delta^{13} \mathrm{C}, \delta^{15} \mathrm{~N}\right)$ and carbon accumulation record from Teringi Bog, an ombrotrophic system in southern Estonia, to reconstruct the timing, magnitude, and direction of centennial- to millennial-scale shifts in hydroclimate and carbon accumulation rates during the late Holocene. Located in the Baltic region, it is sensitive to North Atlantic-driven ocean-atmospheric processes, and therefore also has the potential to provide a local perspective of hydroclimate variability in response to regional circulation dynamics. We compare these new records to insolation [21] and regional proxy data of water table, temperature and precipitation changes to improve the paleo-perspective of climate and carbon dynamics from continental northern Europe.

\section{Study Site}

Teringi Bog $\left(57^{\circ} 58^{\prime} 33^{\prime \prime} \mathrm{N}, 25^{\circ} 33^{\prime} 30^{\prime \prime} \mathrm{E}\right)$ is a rainfall-dominated peatland system in southern Estonia (Figure 1), which is located in the boreo-nemoral vegetation zone [22]. The region was ice covered during the latest Pleistocene as part of the Scandinavian glaciation, and it has remained ice free for the last 14,000 years BP [23]. Teringi, like most peatlands in southern Estonia, sits atop remnant glacial till and sands, although the raised bog conditions have separated most of it from the mineral sediments beneath. 


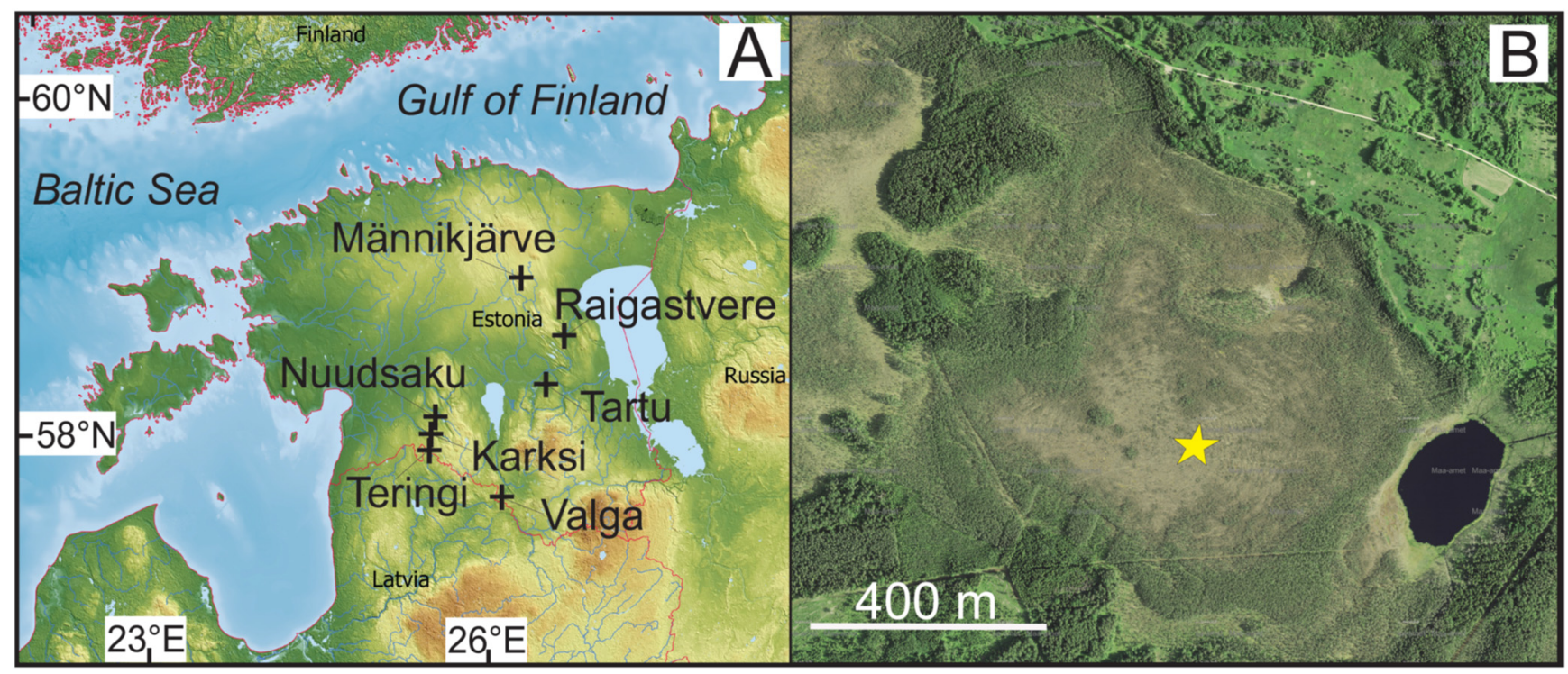

Figure 1. Location map of the study site panels (A) and orthophoto of Teringi Bog panels (B). The yellow star indicates the sampling well and coring location $\left(57^{\circ} 58^{\prime} 33.56^{\prime \prime} \mathrm{N}, 25^{\circ} 33^{\prime} 30.90^{\prime \prime} \mathrm{E}\right)$.

The biodiversity at Teringi is similar to other peatlands in southern Estonia $[24,25]$. In brief summary, the bog is surrounded by mixed forests of Picea (spruce), Betula (birch) and Pinus (pine), as well as cultivated land and meadows. Within the bog, Pinus is the most common tree species, followed by Betula pubescens and Betula nana on the edges (Figure 2). The Pinus forms vary by shape and size based on connectedness to underlying mineral soils and peat thickness. These pines include $f$. litwinowii as the most common throughout the bog, followed by $f$. uliginosa in the areas with more mineral-rich soils, f. wilkommi in areas of thicker peat, and f. pumila in areas of nutrient-poor conditions and thick moss. There are several species of Salix, Sorbus and Populus on the edges of the bog, while Picea, Frangula alnus and Juniperus are less common. The dwarf shrub layer in the bog contains common peatland plants: Caluna vulgaris, Ledum palustre, Andromeda polifolia, Chamaedaphne calyculata and Vaccinium uliginosum. The grass and herb layer consists of Eriophorum vaginatum, Trichophorum cespitosum, Rhynchospora alba, Rubus chamaemorus and Drosera spp. The moss layer contains mostly Polytrichum strictum.

The undecomposed top layer of peat at Teringi is entirely dominated by Sphagnum sect. Acutifolia (e.g., Sphagnum fuscum) and sect. Cuspidata (e.g., Sphagnum angustifolium), which are distributed in relation to the microtopography of the bog. Species comprising the Sphagnum sect. Acutifolia live in hummocks, several centimeters above the water table; species of sect. Cuspidata live much closer to the water surface in lawns or hollows.

Estonia has a temperate climate that is transitional between oceanic and continental, with changes in North Atlantic Ocean-driven circulation dynamics affecting the environmental conditions of the region [26,27]. Stronger westerly zonal winds deliver warmer ocean air to the interior, causing warmer temperatures, while weaker circulation causes colder conditions [28]. The majority of moisture is sourced from the Atlantic Ocean while the Mediterranean Sea and Black Sea provide small secondary sources [29]. The Baltic Sea plays a negligible role in the development of precipitation [30]. Average annual precipitation amounts at Teringi (measured at Valga) are $\sim 685 \mathrm{~mm}$. Average January temperature at Teringi is $\sim-5.5^{\circ} \mathrm{C}$ while July is $\sim 17.3{ }^{\circ} \mathrm{C}$ (Figure 3). 


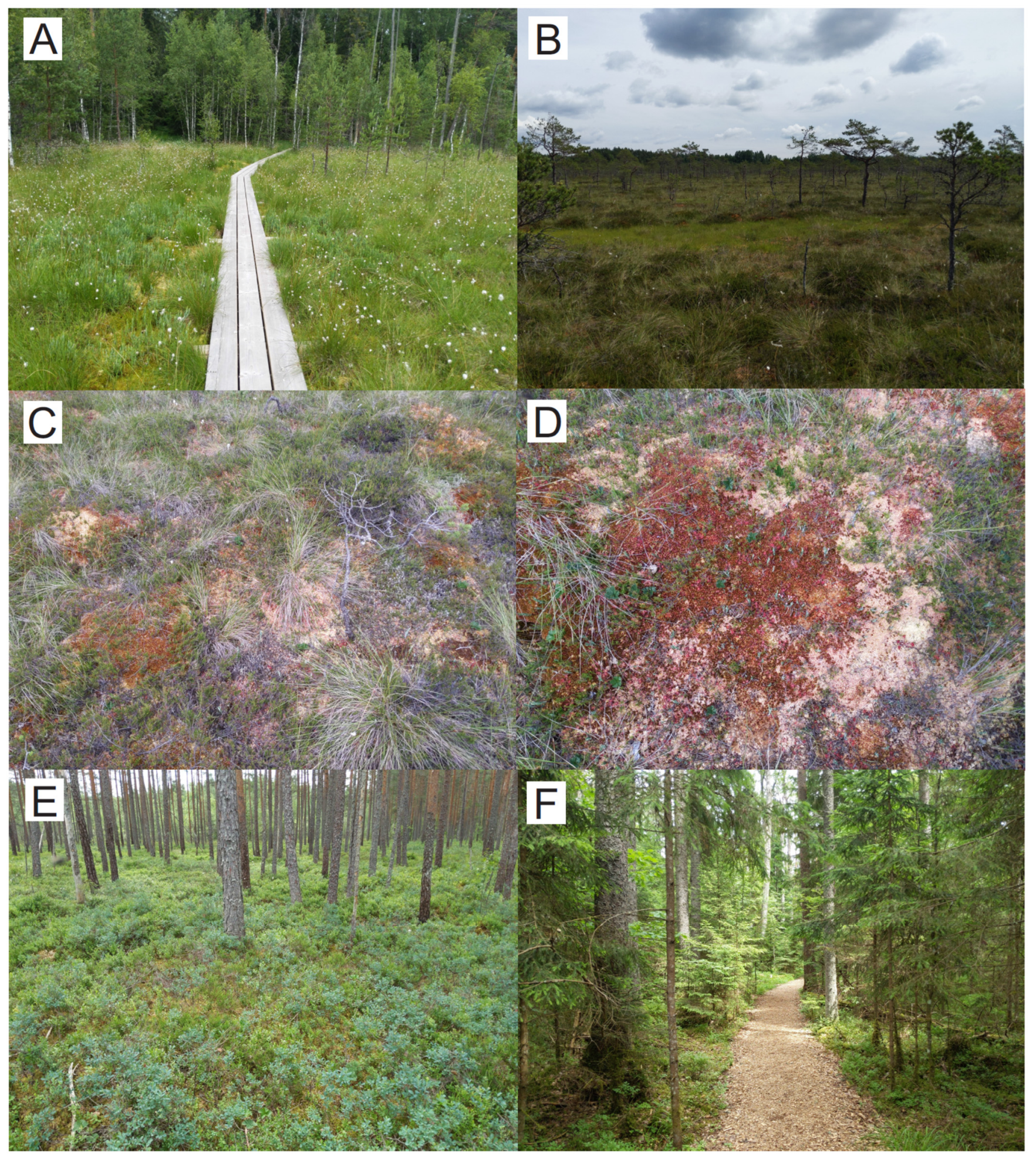

Figure 2. Typical vegetation at Teringi Bog and the surrounding margins. Panel (A) represents the boundary between the open bog and forest. Panels (B-D) are at the coring location in the center of the bog (see Figure 1). Panel (E) represents trees growing near the center of the bog. Panel (F) is the forest on the western edge of Teringi. 


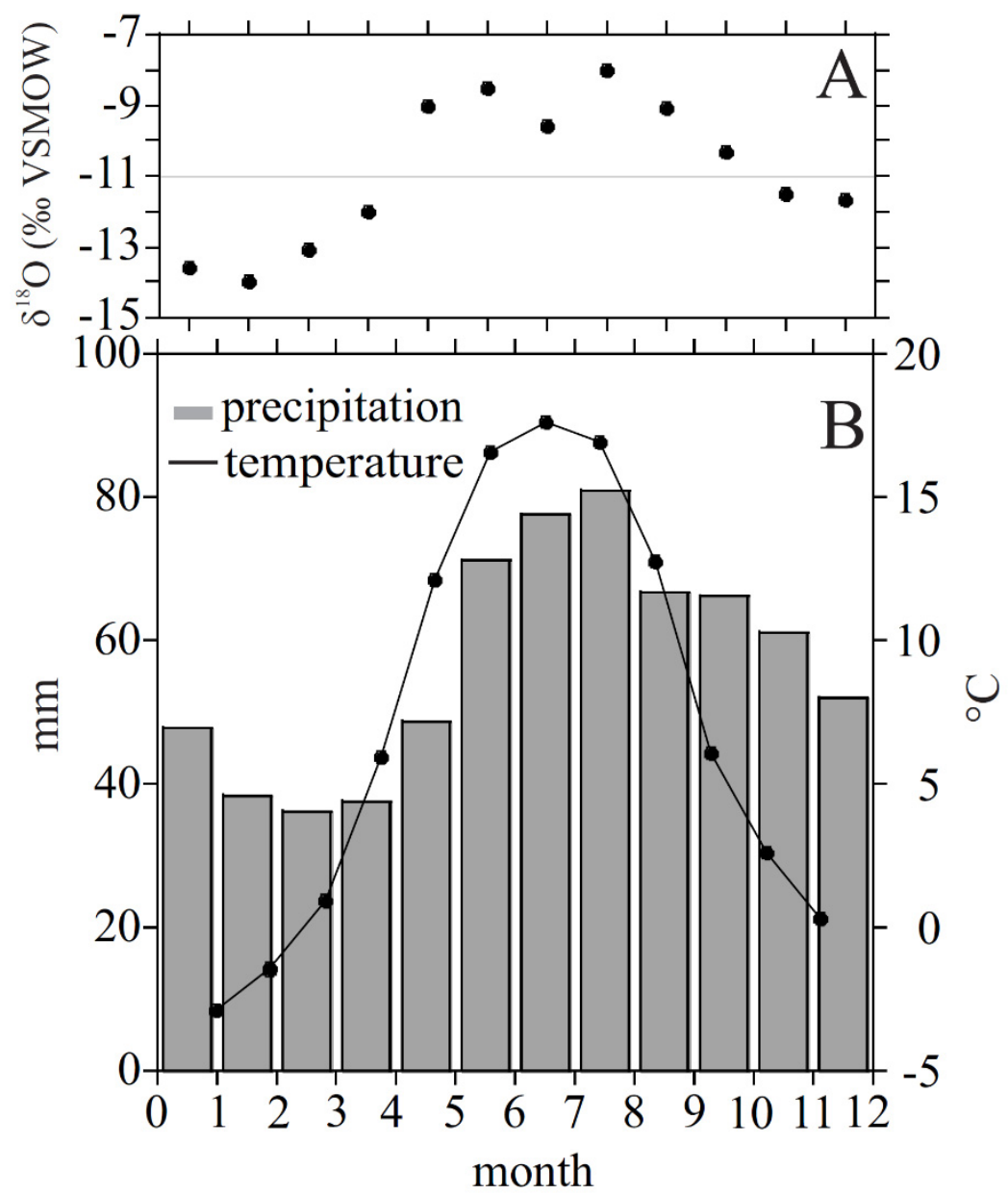

Figure 3. Panel (A): Estonia Global Network of Isotopes in Precipitation (GNIP) precipitationweighted $\delta^{18} \mathrm{O}_{\mathrm{p}}$ data for Tartu shown with average monthly values for 2014 through 2018, with the annual mean shown with a gray solid line. Panel (B): Monthly precipitation and temperature values at Valga, Estonia for the period spanning 1945 to 2020 (Estonian Weather Service).

\section{Materials and Methods}

\subsection{Modern Hydrology}

A water level and temperature logger (Solinst 3001 LT Levelogger Junior) was installed in summer 2014 to monitor hydrological changes, and measurements were collected every hour from 14 August 2014 to 1 July 2021 (Figure 4). The well housing for the logger was constructed of PVC pipe approximately $6 \mathrm{~cm}$ in diameter and $1.1 \mathrm{~m}$ in length. The bottom $\sim 40 \mathrm{~cm}$ of the well contained mesh-covered holes, to allow for equilibration with groundwater and to prevent clogging of the PVC pipe by surrounding peat. The pressure logger was positioned at $\sim 80 \mathrm{~cm}$ depth in the well and both ends of the well were capped. In order to determine changes in peatland water-table depth, the pressure data from the logger was corrected using atmospheric pressure data collected from a barometric logger placed $\sim 2 \mathrm{~m}$ above ground at a location $\sim 15 \mathrm{~km}$ north of the peatlands (Karksi, Estonia, see Figure 1A).

A remote, automated weather station (HOBO U30-NRC and various sensors) was established near the peatland site (also at Karksi, Estonia) in May, 2015 in order to record weather variables including precipitation (tipping bucket), relative humidity (RH) and temperature. Sensors scanned every $1 \mathrm{~min}$ and logged every $1 \mathrm{~h}$ (Figure 4). 


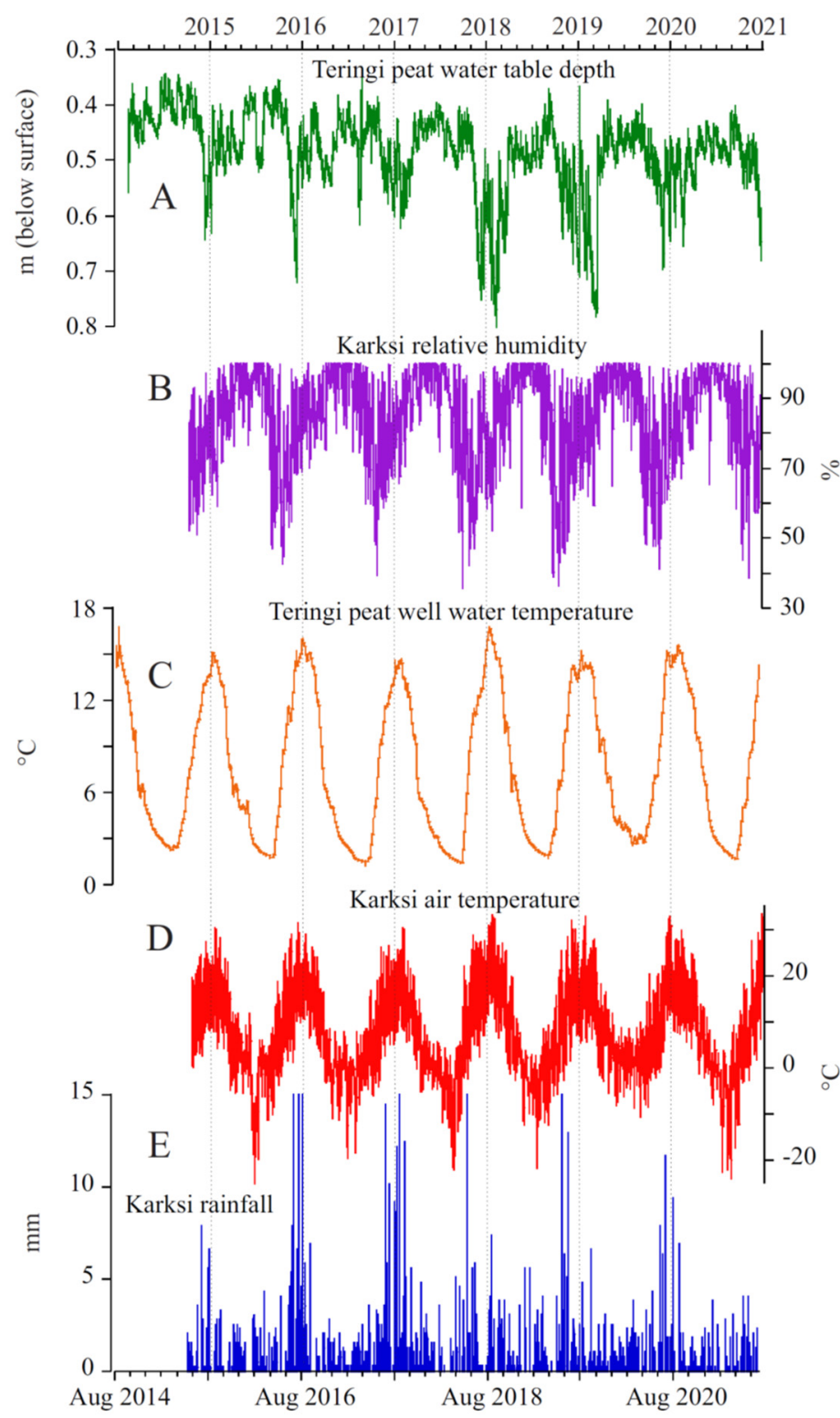

Figure 4. Automatic weather station from Karksi, Estonia (B,D,E) and levelogger data from Teringi Bog $(\mathbf{A}, \mathbf{C})$. The peat water temperature and water level were measured continuously from August, 2014 to July, 2021. The continuous automatic weather station measurements are from May 2015 to July 2021.

\subsection{Modern Water Sampling}

A total of 148 event-based rainfall, lake, wetland, and river samples for $\delta^{18} \mathrm{O}$ and $\delta^{2} \mathrm{H}$ analysis were collected in air-tight $15 \mathrm{~mL}$ vials, with no headspace, and analyzed as part of a multi-year monitoring effort [31]. A total of 26 surface-water and well-water samples were collected across a west-east surface transect through Teringi during the summers of 2014, 2015 and 2016 (Figure 5). An additional 6 surface-water and well-water samples were collected during December, 2014. All Estonia water isotope samples were measured for $\delta^{18} \mathrm{O}$ and $\delta^{2} \mathrm{H}$ ratios using a Piccaro water isotope analyzer in the Stable Isotope Laboratory at the University of Alaska Anchorage. All water samples were screened to verify that organic content was low and not a source of absorption interference spectra [32]. Each sample was then analyzed six times and reanalyzed if the standard deviation of the six replicates was greater than $0.3 \%$ or for $\delta^{18} \mathrm{O}$ and/or $3 \%$ for $\delta^{2} \mathrm{H}$, or if the internal standard for the run differed from the accepted value by greater than $\pm 0.2 \%$ or $2 \%$, for $\delta^{18} \mathrm{O}$ and 
$\delta^{2} \mathrm{H}$, respectively. All isotope results are reported in delta notation $(\delta)$ relative to standards according to the equation $\delta[\%$ o $]=\left(\mathrm{R}_{\text {sample }}-\mathrm{R}_{\text {standard }} / \mathrm{R}_{\text {standard }}\right) * 1000 \%$ [33].

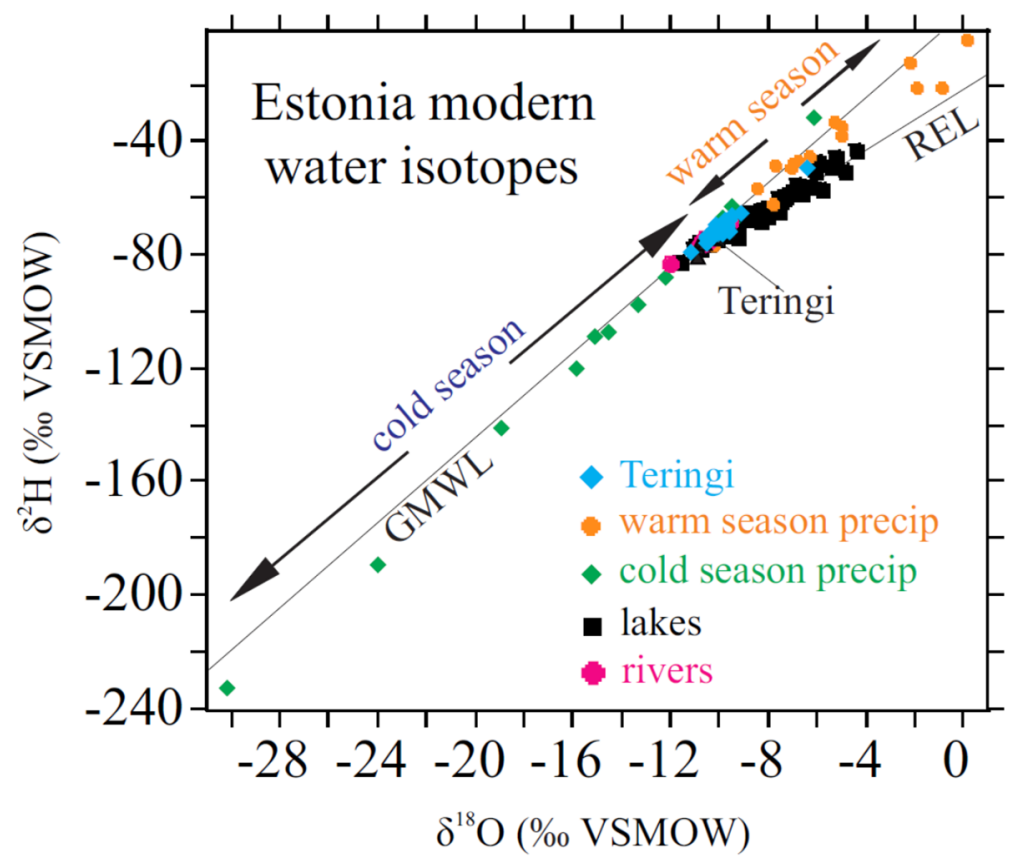

Figure 5. Modern water isotopes from Estonia plotted versus the global meteoric water line (GMWL). The Teringi Bog surface and well water samples plot near the GMWL, reflecting the isotopic composition of source precipitation and the water is a mix of both warm and cold season precipitation. Cold season precipitation samples have relatively low $\delta^{18} \mathrm{O}$ and $\delta^{2} \mathrm{H}$ values, while warm season values are higher. The regional evaporation line (REL), determined from closed-basin lakes in the area, is shown for comparison and plots well below the Teringi Bog surface and well water samples.

\subsection{Core Sample Collection}

A peat record that was $528 \mathrm{~cm}$ in length was collected from the center of Teringi Bog $\left(57^{\circ} 58^{\prime} 33.56^{\prime \prime} \mathrm{N}, 25^{\circ} 33^{\prime} 30.90^{\prime \prime} \mathrm{E}\right)$ by extracting continuous $50 \mathrm{~cm}$ sections from the same location using a Russian peat corer. The corer was unable to penetrate through any material below $528 \mathrm{~cm}$. Cores were extruded in the field into split PVC tubes and wrapped in plastic. The uppermost $\sim 50 \mathrm{~cm}$ of peat were collected separately by hand as a monolith, wrapped in plastic and stored in PVC tubing. All peat samples were kept in refrigerated storage after collection.

\subsection{Chronology}

Age control for the composite peat record was established using accelerator mass spectrometry (AMS) ${ }^{14} \mathrm{C}$ analysis of discrete peat (Sphagnum) stem material (Table 1). The ${ }^{14} \mathrm{C}$ samples were pretreated at Northern Illinois University using standard acid-baseacid wash techniques and processed and measured at the W.M. Keck Carbon Cycle AMS Laboratory at the University of California, Irvine. The ${ }^{14} \mathrm{C}$ ages were calibrated using the IntCal20 calibration curve [34]. An age-depth model was created using a cubic spline interpolator with Bayesian statistical methods [35], and the peat core time-series data presented are based on the weighted mean ages modeled using Bacon software in $R$ (Figure 6). 
Table 1. Radiometric ages used in study. All samples were measured on Sphagnum stems.

\begin{tabular}{|c|c|c|c|c|c|c|c|}
\hline${ }^{14} \mathrm{C}$ Age & $\begin{array}{c}\text { Analytical } \\
\text { Uncertainty } \pm 1 \sigma\end{array}$ & $\begin{array}{c}\text { Median } \\
\text { Calibrated } \\
\text { Age (cal yr BP) }\end{array}$ & $\begin{array}{l}\text { Minimum } \\
\text { Calibrated Age } \\
\text { (cal yr BP) } 2 \sigma\end{array}$ & $\begin{array}{c}\text { Maximum } \\
\text { Calibrated } \\
\text { Age (cal yr BP) } \\
2 \sigma\end{array}$ & $\begin{array}{c}\text { Weighted } \\
\text { Mean } \\
\text { Modeled Age } \\
\text { (cal yr BP) }\end{array}$ & 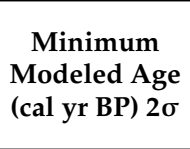 & $\begin{array}{c}\text { Maximum } \\
\text { Modeled Age } \\
\text { (cal yr BP) } 2 \sigma\end{array}$ \\
\hline-65 & 1 & & & & -65 & -68 & -62 \\
\hline 140 & 15 & 109 & 58 & 118 & 172 & 63 & 271 \\
\hline 1545 & 15 & 1405 & 1369 & 1419 & 1401 & 1351 & 1488 \\
\hline 2025 & 15 & 1963 & 1925 & 2000 & 1968 & 1901 & 2043 \\
\hline 2380 & 20 & 2392 & 2346 & 2465 & 2442 & 2352 & 2654 \\
\hline 3075 & 15 & 3291 & 3232 & 3358 & 3297 & 3218 & 3363 \\
\hline 3810 & 20 & 4195 & 4145 & 4252 & 4200 & 4097 & 4347 \\
\hline
\end{tabular}

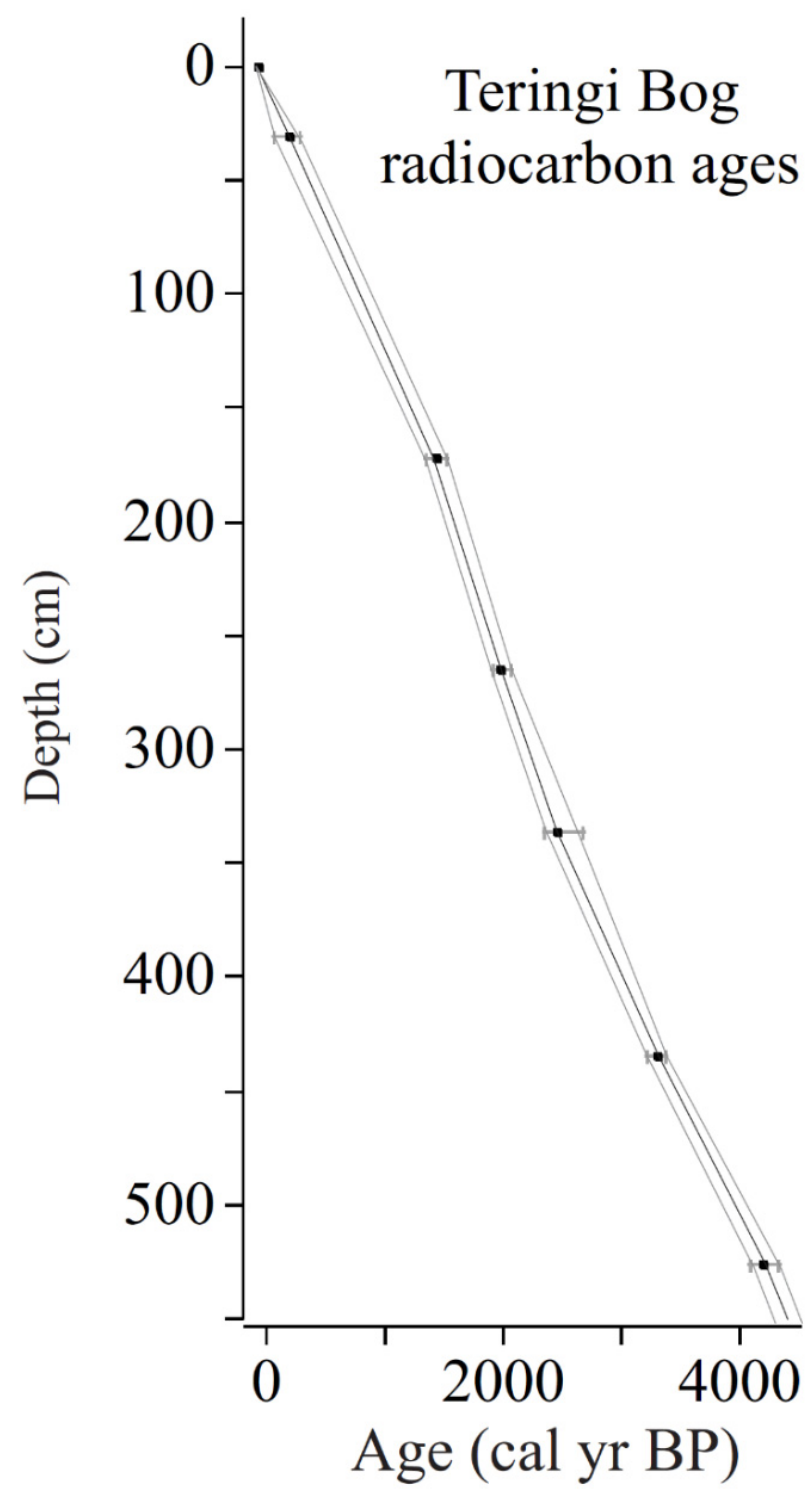

Figure 6. Age-depth model for Teringi Bog calculated with Bacon. The horizontal bars and grey lines represent the modeled calibration range of each ${ }^{14} \mathrm{C}$ sample (see Table 1 ). 


\subsection{Species Identification}

The core was sampled every $10 \mathrm{~cm}$ for species identification, and bulk Sphagnum sp. remains were placed in a small Petri dish and submerged in distilled water. Approximately 20 to 50 leaves were mounted on glass microscope slides, and individual species were determined by leaf morphology and placement of pores in the leaf structure under $40 \times-100 \times$ magnification following established methods [36] (Figure 7).

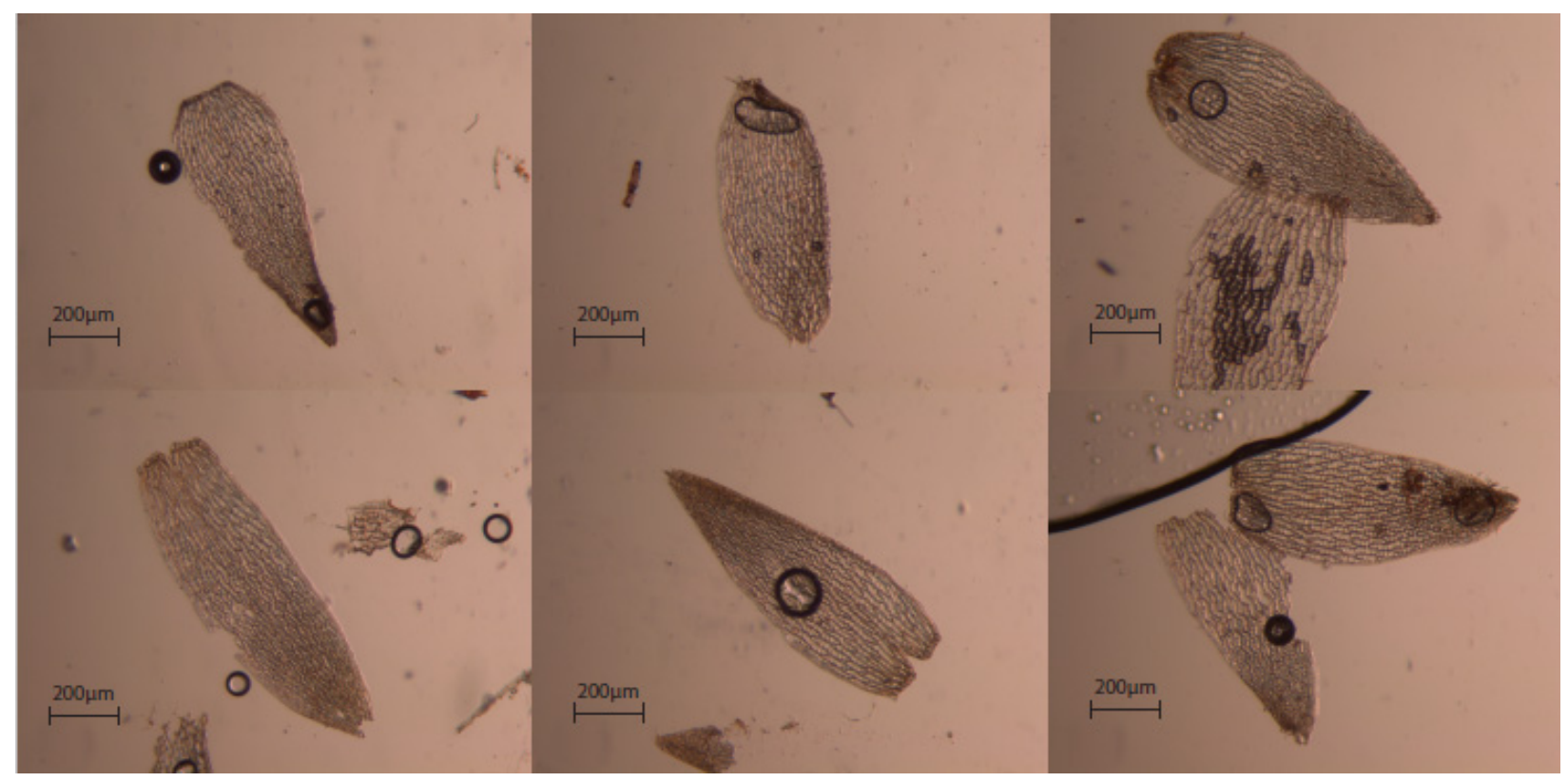

Figure 7. Sample leaf morphologies used for modern species identification (Hill, 2016). The top left panel is S. fuscum, top middle is S. capillifolium, top right is S. rubellum, bottom left is likely S. balticum, bottom middle is $S$. fallax and bottom right is $S$. pulchrum.

\subsection{Carbon and Nitrogen Concentrations and Stable Isotopes}

A total of 53 samples were collected down-core from sections $1 \mathrm{~cm}$ in thickness. Samples that contained both stems and branches were collected consistently down-core following standard methods [37]. The samples were dried overnight at $70{ }^{\circ} \mathrm{C}$ in a drying oven and homogenized using a combination of mortar and pestle and razor blade. The dried and homogenized material was weighed (approximately $3 \mathrm{mg}$ for $\mathrm{N}$ and $0.3 \mathrm{mg}$ for $\mathrm{C}$ ) and loaded into tin capsules. Isotopic analyses and total carbon and nitrogen concentrations were conducted at the Stable Isotope Laboratory at the Environmental and Natural Resources Institute at University of Alaska Anchorage. Carbon $\left(\delta^{13} \mathrm{C}\right)$ and nitrogen $\left(\delta^{15} \mathrm{~N}\right)$ isotope values, as well as $\mathrm{C}$ and $\mathrm{N}$ concentrations were measured using a coupled Costech Instruments elemental analyzer and ThermoFinnigan Electron Delta Plus XP continuous flow isotope ratio mass spectrometer (IRMS). All isotope values were calibrated with internal standards. Analytical precision was $0.08 \%$ for carbon and $0.1 \%$ for nitrogen.

Bulk density and loss on ignition (LOI) was also measured on $1 \mathrm{~cm}^{3}$ samples collected every $4 \mathrm{~cm}$ down-core at $550{ }^{\circ} \mathrm{C}$ to estimate the percent organic matter [38-40]. Organic carbon content was determined by multiplying the amount of organic matter by 0.423 , the typical value used for Sphagnum-dominated systems [41]. Flux of organic carbon was determined for both the IRMS and LOI data by multiplying the percent of organic carbon of dry bulk density $\left(\mathrm{g} / \mathrm{cm}^{3}\right)$ by the accumulation rate $(\mathrm{cm} / \mathrm{yr})$ (Figures 8 and 9). 

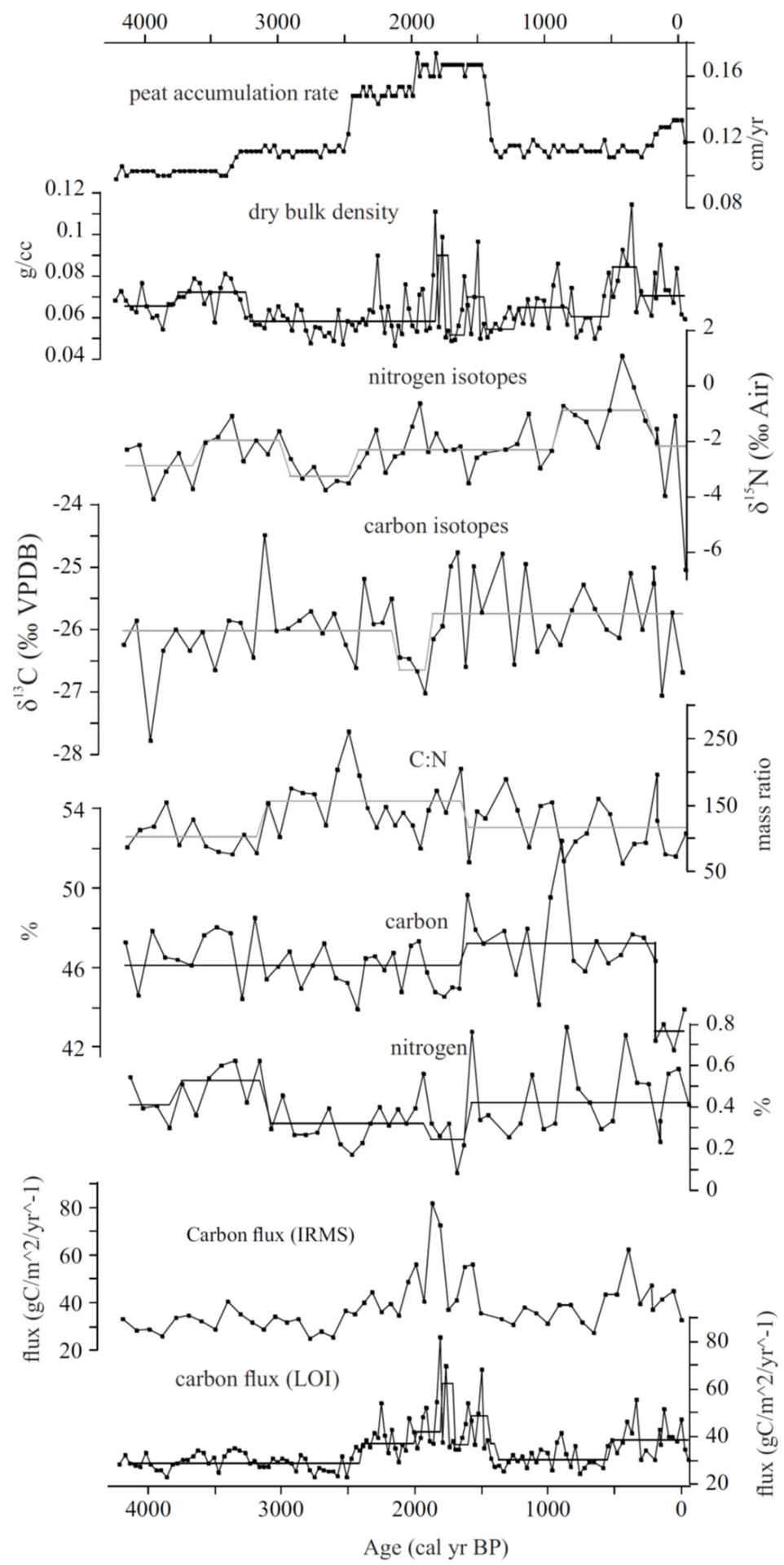

Figure 8. Peat core data. Solid black lines represent the mean values computed by regime-shift analysis.

Time-series analyses were performed on all environmental datasets. Significant regime shifts in all time-series data were identified using Sequential Regime Shift Detection software (v. 6.2) [42], with a 95\% confidence level, a cutoff length of 5, and a Huber's tuning constant of 1 (Figures 8 and 9). A Principal Component Analysis (PCA) of the sedimentological, stable isotope $\left(\delta^{13} \mathrm{C}\right.$ and $\left.\delta^{15} \mathrm{~N}\right)$ and bulk geochemical data was done using the $\mathrm{R}$ FactoMineR package [43], after scaling the data by variance (Figure 10). The PCA also includes late Holocene temperature data from Fennoscandia [44] and water table data from Männikjärve Bog in Estonia [45]. 


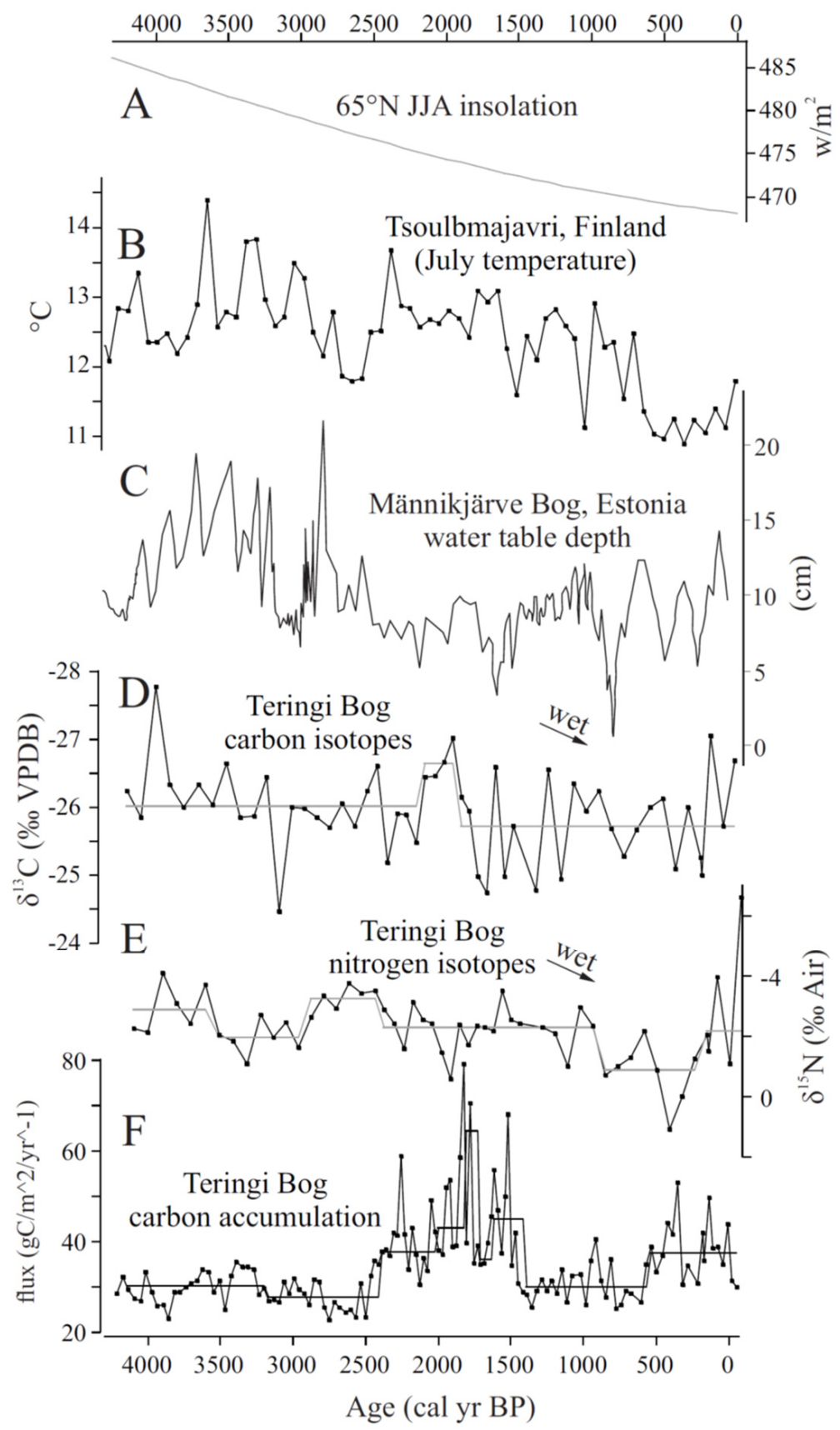

Figure 9. Teringi Bog data plotted versus regional paleoclimate records mentioned in text. Summer insolation (A) [21] decreased through the late Holocene as there was an overall trend to lower temperatures recorded in lake sediment records (B) [44]. Fluctuations in water table depth recorded at Männikjärve Bog in Estonia (C) [45] generally correspond to changes in hydroclimate recorded in the carbon (D) and nitrogen (E) isotope records from Teringi Bog. Note the inverted vertical axes for $\delta^{13} \mathrm{C}$ and $\delta^{15} \mathrm{~N}$. The carbon accumulation rates at Teringi Bog $(\mathbf{F})$ were generally higher under wetter conditions during the late Holocene. 


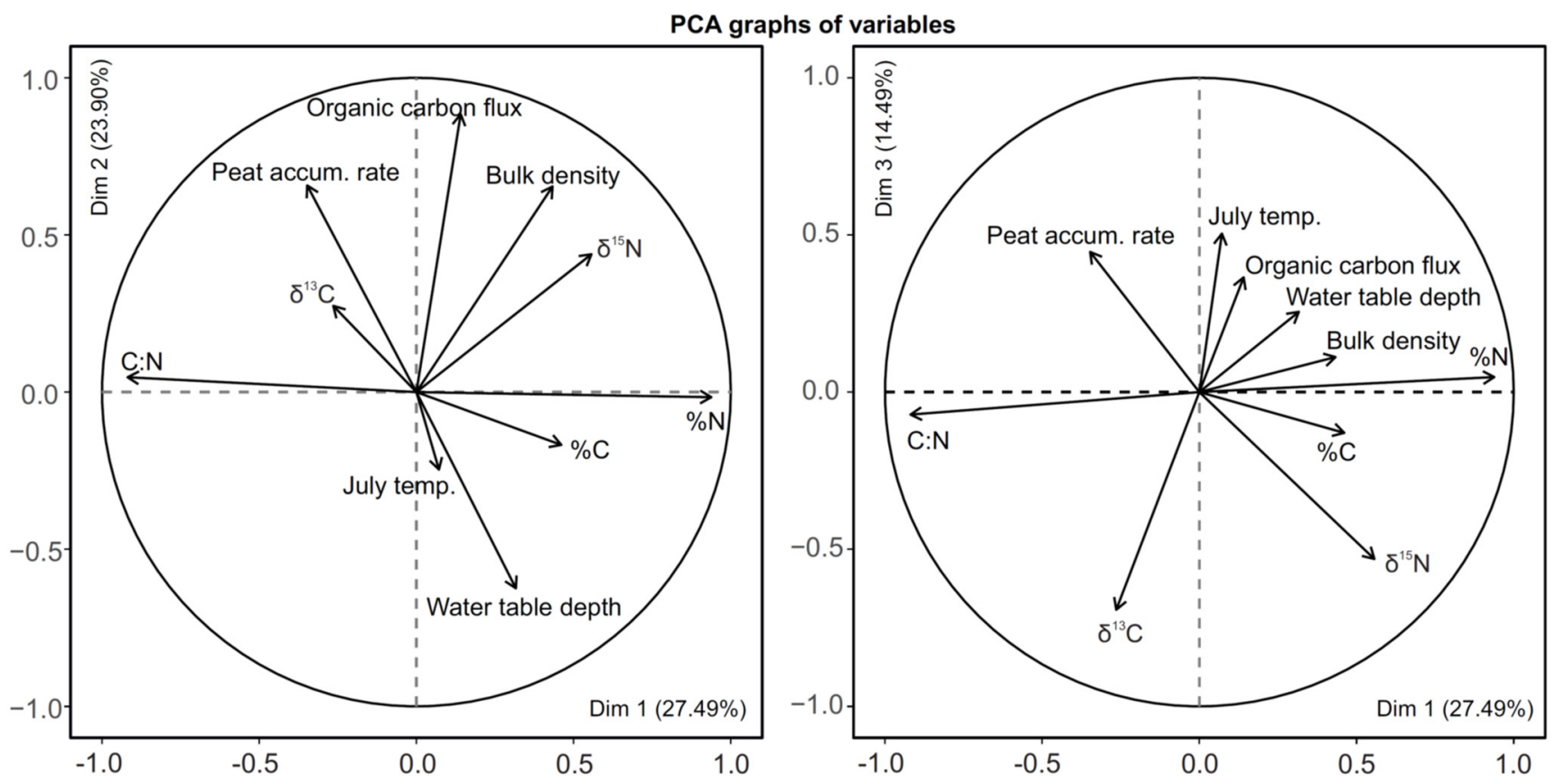

Figure 10. PCA of Teringi Bog core data and regional paleoclimate records of water table fluctuations [45] and July temperatures recorded in the Baltic region [44].

\section{Results}

\subsection{Weather Station Data}

Weather station data reveal variations consistent with seasonal changes (Figure 4). The seasonal patterns, as well as the maximum and minimum values of the air temperature data from the automated weather station at Karksi are similar to the 30 year averages of reprocessed data for the region (Figure 3). Temperatures are highest from late May through September, peaking in late July and early August. The coldest temperatures are from January through March. Precipitation events occur throughout the year, with generally wetter conditions in late summer and fall. The measured precipitation values in winter are well below the 30 year averages from Valga, but this is likely because the battery powered weather station at Karksi is incapable of recording accurate winter precipitation amounts. Relative humidity values are highest in late fall through winter, lowest in spring, and intermediate through summer.

Peatland water temperatures varied seasonally, and as expected, the magnitude of changes was lower than that of air temperatures (Figure 4). The highest water temperatures are generally from June through September, peaking in late July and early August. The coldest temperatures are generally from January to April. There is an apparent abrupt increase in temperature at the bog during the spring melt season and this lag relative to changes in air temperature might be exaggerated as the ice covered datalogger probably records the onset of thawed conditions. The water-level data revealed sharp drawdowns of water levels from May through September of most years. Water levels generally remain low during the early-to-mid summer months, followed by fluctuating but relatively high values through late summer, fall, winter and early spring.

\subsection{Surface Water and Precipitation Stable Isotopes}

Surface water and precipitation isotope values vary seasonally and by location (Figure 5). Cold season (November-April) precipitation and surface water samples have relatively low $\delta^{18} \mathrm{O}$ values, generally in the range of $\sim-23$ to $-9 \%$ VSMOW, while warm season (MayOctober) values are higher ( - 10 to $0 \%$ VSMOW). For comparison, the Teringi Bog, river, and other open-basin lakes all plot near the global meteoric water line (GMWL) with little to no influence of evaporation. The bog samples collected between May and August from both 
the well and surface water generally range from $\sim-10.5 \%$ o to $-9.1 \%$ VSMOW. Surface water samples collected across the bog in December range from - $18.9 \%$ o to $-9.0 \%$ VSMOW while the well water at the coring site was $-9.5 \%$ VSMOW.

\subsection{Chronology}

The initial ${ }^{14} \mathrm{C}$, calibrated, and Bayesian age-depth model results are presented in Table 1 and Figure 6 . The record spans the last $\sim 4200$ years with no hiatuses. The youngest sample $\left(140{ }^{14} \mathrm{C} \mathrm{BP}\right)$ ranged from $\sim 60$ to $120 \mathrm{cal}$ yr BP with a median probability of $110 \mathrm{cal}$ yr BP, and a weighted mean modeled age of 270 cal yr BP. The other 5 samples have median probability values that are within the $>90 \%$ probability distributions and the weighted mean modeled ages are within the 2-sigma calibrated age ranges.

\subsection{Species Identification}

Acutifolia was the primary Sphagnum section throughout the core (Figure 7 and Table 2), and the dominant species were S. fuscum and S. capillifolium [46]. S. fuscum, S. capillifolium and S. angustifolium make up the bulk of the record from $\sim 4200$ to 3960 cal yr BP. S. fuscum, S. capillifolium and S. medium are dominant from $\sim 3960$ to 2920 cal yr BP, followed by S. fuscum, S. capillifolium and S. russowii from 2920 to $1700 \mathrm{cal} \mathrm{yr} \mathrm{BP,} \mathrm{and} \mathrm{then} \mathrm{S.} \mathrm{fuscum,}$ S. capillifolium and S. angustifolium from $\sim 1700$ to $1130 \mathrm{cal}$ yr BP. S. fuscum and S. capillifolium are dominant from $\sim 1130$ to $960 \mathrm{cal}$ yr BP, followed by S. fuscum and S. rubellum from $\sim 960$ to $700 \mathrm{cal}$ yr BP. From $700 \mathrm{cal}$ yr BP to the modern, species are much more diverse and include S. fuscum and S. capillifolium, S. rubellum, S. balticum, S. fallax, and S. pulchrum.

\subsection{Peat Stable Isotope Records}

The $\delta^{13} \mathrm{C}$ values range from $\sim-27.8 \%$ to $-24.5 \%$ (VPDB), which is typical of $\mathrm{C}_{3}$ forming peat plants [47]. The $\delta^{13} \mathrm{C}$ values were intermediate from $\sim 4130$ to 2130 cal yr BP, followed by lower values until $\sim 1810 \mathrm{cal}$ yr BP and a return to intermediate values through the modern. The $\delta^{13} \mathrm{C}$ values show an overall increasing trend from the beginning of the late Holocene to the present.

The $\delta^{15} \mathrm{~N}$ values ranged from $\sim-6.6 \%$ o to $1 \%$ o (versus air), with most values varying between $\sim-4 \%$ o to $0 \%$ o (Figures 8 and 9 ). The $\delta^{15} \mathrm{~N}$ values were low from $\sim 4130$ to $3645 \mathrm{cal}$ yr BP, followed by intermediate values until $\sim 2995 \mathrm{cal}$ yr BP, and a shift to lower values until $\sim 2470$ cal yr BP. The $\delta^{15} \mathrm{~N}$ values were then intermediate until $\sim 955$ cal yr BP, followed by higher values until $\sim 250 \mathrm{cal}$ yr BP, and then a return to intermediate levels through the modern. The lowest $\delta^{15} \mathrm{~N}$ value was in the upper-most $(2 \mathrm{~cm})$ sample of the core.

\subsection{Carbon, Nitrogen and Carbon Accumulation Rates}

The bulk density values were intermediate from 4200 to 3350 cal yr BP, followed by lower values until 1860 cal yr BP, and then a return to high values until $1790 \mathrm{cal}$ yr BP. Values then decreased until $1675 \mathrm{cal}$ yr BP, followed by high values until $1500 \mathrm{cal}$ yr BP, and a return to lower values until 1295 cal yr BP. Values were then intermediate until $\sim 585$ cal yr BP, followed by a shift to higher values until $\sim 340$ cal yr BP. Bulk density returned to intermediate values through the modern.

The mass ratios of $C$ and $N(C: N)$ were low from $~ 4130$ to 3170 cal yr BP, followed by higher values until $\sim 1630 \mathrm{cal}$ yr BP and a return to low values through the modern. The $\% \mathrm{C}$ values were intermediate from $\sim 4130$ to 1630 cal yr BP, followed by a slight increase until $\sim 170$ cal yr BP and then a shift to lower values through the modern. The $\% \mathrm{~N}$ values were intermediate from $\sim 4130$ to 3840 cal yr BP, followed by higher values until $\sim 3170$ cal yr BP. There was then a return to lower \% N values until $~ 1630$ cal yr BP, followed by intermediate values through the modern. 
Table 2. Sphagnum species identification at each sampled depth. A ' 1 ' indicates that a species was the most common at that interval. A ' 2 ' indicates that the species was present, but not the most common.

\begin{tabular}{|c|c|c|c|c|c|c|c|c|c|c|c|c|}
\hline \multirow[b]{2}{*}{ Depth (cm) } & \multirow[b]{2}{*}{ Age (cal yr BP) } & \multicolumn{4}{|c|}{ Section Acutifolia } & \multicolumn{5}{|c|}{ Section Cuspidata } & \multirow{2}{*}{$\begin{array}{c}\begin{array}{c}\text { Section } \\
\text { Subsecunda }\end{array} \\
\text { spp. }\end{array}$} & \multirow{2}{*}{$\begin{array}{c}\begin{array}{c}\text { Section } \\
\text { Sphagnum }\end{array} \\
\text { S. medium }\end{array}$} \\
\hline & & S. fuscum & S. capilli-folium & S. rubellum & S. russowi & S. pulchrum & S. fallax & S. angusti-folium & S.balticum & S. lind-bergii & & \\
\hline 32 & 182 & & & & & 2 & 2 & & & & & \\
\hline 42 & 266 & 2 & & & & & & 1 & & & & \\
\hline 52 & 352 & & 1 & 2 & & & & & 2 & & & \\
\hline 62 & 439 & 1 & & & & & & & 2 & & & \\
\hline 72 & 525 & 1 & & & & & & & & & & \\
\hline 82 & 613 & 2 & 2 & & & & & & & 2 & & \\
\hline 92 & 699 & 2 & 2 & & & & 2 & & 2 & & & \\
\hline 102 & 786 & 2 & & 1 & & & & & & & & \\
\hline 112 & 870 & & & 1 & & & & & & & & \\
\hline 122 & 957 & 2 & 1 & & & & & & & & & \\
\hline 132 & 1042 & & 1 & & & & & & & & & \\
\hline 142 & 1130 & 1 & 2 & & & & & & & & 2 & \\
\hline 152 & 1220 & 1 & & & & & & & & & 2 & \\
\hline 162 & 1311 & 2 & 2 & & & & & 1 & & & & \\
\hline 182 & 1460 & 1 & 2 & & 2 & & & 2 & & & & \\
\hline 192 & 1521 & 1 & & & & & & 2 & & & & \\
\hline 202 & 1581 & 1 & & & & & & & & & & \\
\hline 212 & 1642 & 2 & 2 & & & & & 1 & & & & \\
\hline 222 & 1701 & 1 & 1 & & 2 & & & & & & & \\
\hline 232 & 1762 & 1 & 1 & & & & & & & & 2 & \\
\hline 242 & 1823 & 2 & 1 & & & & & & & & & \\
\hline 252 & 1885 & 2 & 1 & & & & & & & & & \\
\hline 262 & 1946 & 1 & 2 & & & & & 2 & & & & \\
\hline
\end{tabular}


Table 2. Cont.

\begin{tabular}{|c|c|c|c|c|c|c|c|c|c|c|c|c|}
\hline \multirow[b]{2}{*}{ Depth $(\mathrm{cm})$} & \multirow[b]{2}{*}{ Age (cal yr BP) } & \multicolumn{4}{|c|}{ Section Acutifolia } & \multicolumn{5}{|c|}{ Section Cuspidata } & \multirow{2}{*}{$\begin{array}{c}\begin{array}{c}\text { Section } \\
\text { Subsecunda }\end{array} \\
\text { spp. }\end{array}$} & \multirow{2}{*}{$\begin{array}{c}\begin{array}{c}\text { Section } \\
\text { Sphagnum }\end{array} \\
\text { S. medium }\end{array}$} \\
\hline & & S. fuscum & S. capilli-folium & S. rubellum & S. russowi & S. pulchrum & S. fallax & S. angusti-folium & S.balticum & S. lind-bergii & & \\
\hline 272 & 2011 & 1 & 2 & & & & & & & & & \\
\hline 282 & 2078 & 1 & 2 & & & & & & & & & \\
\hline 292 & 2144 & 1 & 2 & & & & & & & & & \\
\hline 302 & 2210 & 1 & 2 & & & & & & & & & \\
\hline 312 & 2276 & 1 & 2 & & & & & 1 & & & & \\
\hline 322 & 2343 & 1 & & & & & & & & & & \\
\hline 332 & 2411 & 1 & 2 & & 2 & & & & & & & \\
\hline 342 & 2487 & 1 & & & 2 & & & & & & & 2 \\
\hline 352 & 2575 & 1 & 2 & & & & & & & & & 2 \\
\hline 362 & 2663 & 1 & 2 & & & & & & & & & \\
\hline 372 & 2750 & 2 & 1 & & & & & & & & & \\
\hline 382 & 2837 & 2 & 1 & & & & & & & & & \\
\hline 392 & 2923 & 2 & 1 & & & & & & & & & 2 \\
\hline 402 & 3011 & 1 & 2 & & & & & & & & & \\
\hline 422 & 3187 & 1 & 2 & & & & & & & & & \\
\hline 432 & 3275 & 1 & 2 & & & & & & & & & \\
\hline 442 & 3370 & 1 & & & & & & & & & & \\
\hline 452 & 3469 & 1 & 2 & & & & & & & & & \\
\hline 462 & 3567 & 1 & & & & & & & & & & \\
\hline 472 & 3665 & 1 & & & & & & 1 & & & & \\
\hline 482 & 3764 & 1 & & & & & & & & & & \\
\hline 492 & 3862 & 1 & & & & & & 1 & & & & \\
\hline 502 & 3959 & 1 & 2 & & & & & 1 & & & & \\
\hline 512 & 4055 & 1 & & & & & & & & & & \\
\hline 522 & 4154 & 1 & & & & & & & & & & \\
\hline
\end{tabular}


The carbon accumulation (flux) rates for the LOI and IRMS methods produced similar results. The percentage of organic matter in all the LOI samples was $>97 \%$, and we thus assume that any mineral sediments are negligible. The carbon accumulation rates were low

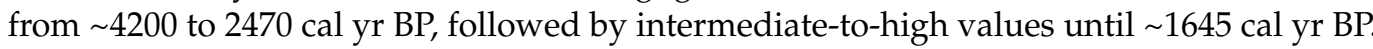
Carbon accumulation rates were then lower until $\sim 585 \mathrm{cal}$ yr BP, followed by a return to intermediate values through the modern.

\subsection{Principal Component Analysis}

The results of the PCA (Table 3 and Figure 10) highlight varying associations between past changes in water table depth, temperature and proxies for environmental changes at Teringi Bog. For example, the $\% \mathrm{~N}$ and C:N data correlate strongly with PC1 as shown with high positive (0.94) and negative loadings $(-0.92)$. The $\% \mathrm{C}$ values have only a 0.46 loading with PC1 and do not correlate strongly with either PC2 or PC3. Organic carbon flux, peat accumulation rates and bulk density correlate with PC2 with loadings of 0.88 , 0.66 and 0.65 . Water table depths also have a moderately strong correlation with PC2 with a loading of -0.62 . July temperatures, peat accumulation rates and $\tilde{~}^{13} \mathrm{C}$ correlate with PC3 with loadings of $0.50,0.45$ and -0.69 . The $\tilde{o}^{15} \mathrm{~N}$ values weakly correlate with PC1, PC2 and PC3 with loadings of $0.56,0.44$ and -0.53 .

Table 3. Correlation coefficients for PCA ( $p$ values are all <0.001).

\begin{tabular}{llll}
\hline Variable & Dim. 1 & Dim. 2 & Dim. 3 \\
\hline \%N & 0.938 & -0.016 & 0.048 \\
\hline C:N & -0.918 & 0.047 & -0.072 \\
\hline$\tilde{\mathrm{o}}^{15} \mathrm{~N}$ & 0.557 & 0.439 & -0.531 \\
\hline Organic C flux & 0.141 & 0.884 & 0.365 \\
\hline Peat accum. Rate & -0.347 & 0.657 & 0.446 \\
\hline Bulk density & 0.433 & 0.654 & 0.111 \\
\hline Water table depth & 0.316 & -0.624 & 0.255 \\
\hline$\tilde{\text { o }}^{13} \mathrm{C}$ & -0.264 & 0.274 & -0.692 \\
\hline July temp & 0.072 & -0.246 & 0.504 \\
\hline \%C & 0.461 & -0.168 & -0.13 \\
\hline
\end{tabular}

\section{Discussion}

\subsection{Surface Water Source and Seasonality}

The $\delta^{18} \mathrm{O}_{\mathrm{p}}$ of mid-to-high latitude rainfall is primarily controlled by air mass distillation and atmospheric temperature $[48,49]$. This results in a positive correlation between winter $\delta^{18} \mathrm{O}_{\mathrm{p}}$ and temperature in Europe [50]. Additionally, Punning et al. [30] identified a temperature gradient of isotopic composition of $\delta^{18} \mathrm{O}_{\text {surfacewater }}$ of $0.32 \% /{ }^{\circ} \mathrm{C}$ for Estonia. Moreover, there is a strong negative correlation between winter (December-March) precipitation amount and $\delta^{18} \mathrm{O}_{\mathrm{p}}$ [50], indicating that seasonality is a dominant driver of $\delta^{18} \mathrm{O}_{\mathrm{p}}$ variability recorded in Estonian surface waters. Variations in snow pack thickness [51,52] should be negligible for precipitation-fed systems like Teringi that lack other water sources [53]. Most of the surface water $\delta^{18} \mathrm{O}$ values for samples collected from Teringi vary only by $\sim 2 \%$ throughout the year (from -11 to $-9 \%$ ), which are intermediate between warm and cold season precipitation values recorded at the nearby Tartu GNIP station (Figure 3). This suggests that the bog water is an integration of several months of precipitation and that the residence time of water in the bog is probably at least several months to years. There appears to be little or no direct influence of surface evaporation on the water within the bog, suggesting that water loss is preferentially through transpiration and sub-surface flow. 
The local weather station and water-logger data suggest that the timing of water level fluctuations corresponds most closely to changes in $\mathrm{RH}$, followed by temperature and rainfall changes (Figure 4). For example, the water-logger data revealed sharp drawdowns of water levels from May through September of most years when $\mathrm{RH}$ values were low to intermediate. Water levels generally remained low during the early-to-mid summer months when temperatures were high and there were fewer rainfall events. Water levels then fluctuated but remained relatively high through late summer, fall, winter and early spring. These modern observations of environmental conditions suggest that changes in either hydroclimate or temperatures had the potential to impact the carbon dynamics and greenhouse gas exchanges at Teringi during the late Holocene.

\subsection{Changes in Sphagnum}

Species of Sphagnum shift under changing environmental conditions. For example, S. fuscum and S. capillifolium tend to be more productive under stressful conditions [54], and $S$. rubellum are more productive at higher temperatures [55]. Hummock species like S. fuscum and $S$. medium are generally more resistant to drought than lawn or hollow species like $S$. balticum and $S$. russowi that typically represent wetter periods $[45,56,57]$. Lab experiments indicate that $S$. rubellum is generally unaffected by modest water table changes [55]. S. angustifolium is better than species like S. fallax at growing under drier and warmer conditions [58].

We therefore broadly interpret wetter intervals as times when S. balticum and/or S. russowi increase, warmer and/or drier intervals when S. medium, S. angustifolium and/or S. rubellum have higher proportions, and intermediate conditions when S. fuscum and/or S. capillifolium dominate. It should be noted that the typical time needed for hollow species to replace hummocks in Estonia is 180 years, and 320 years are required for hummock species to replace hollows [45]. Acknowledging that there is a lag in the plant response time that has not been accounted for here, the composition of the core suggests that the climate was overall warm and dry from 4200 to 3960 cal yr BP, followed by intermediate-to-dry conditions until $\sim 2920$ cal yr BP. Conditions were generally wetter from $\sim 2920$ to 1700 cal yr $\mathrm{BP}$, followed by a shift to somewhat warmer and drier conditions until $1130 \mathrm{cal}$ yr BP. The climate conditions were milder from 1130 to 960 cal yr BP, followed by higher temperatures until $\sim 700 \mathrm{cal}$ yr BP. The remaining section of the core with abundant species variations through the modern likely represents overall wetter conditions and intermediate-to-cold temperatures.

\subsection{Carbon and Nitrogen Isotopes}

Carbon isotopes in peatland systems are affected by multiple environmental processes, but in certain conditions they can be an additional indicator of bog surface wetness [15]. Sphagnum mosses lack guard cells surrounding their stomata, so they cannot regulate their uptake of atmospheric $\mathrm{CO}_{2}$, and the $\delta^{13} \mathrm{C}$ value reflects the relative wetness or dryness of the plant's environment. The $\mathrm{CO}_{2}$ enters the Sphagnum leaf through the stomata into the large and dead hyaline cells, and it must then pass through a membrane between the hyaline and photosynthetic cells before it can be utilized for photosynthesis [59]. When the hyaline cells are filled with air, $\mathrm{CO}_{2}$ can more easily diffuse through the membrane, allowing the plant to preferentially uptake the lighter isotope, which leads to lower $\delta^{13} \mathrm{C}$ values. When the hyaline cells are filled with water, diffusion is more difficult, and the plant cannot discriminate against the heavy isotope as easily, leading to higher $\delta^{13} \mathrm{C}$ values. For Sphagnum mosses, once the $\mathrm{CO}_{2}$ enters the photosynthetic cells, the process of fixing $\mathrm{CO}_{2}$ into usable compounds produces a fractionation of approximately $-26.5 \%[59,60]$

In ombrotrophic bogs, Sphagnum takes in nitrogen directly from the atmosphere and water [16], and measurements of nitrogen isotopes $\left(\delta^{15} \mathrm{~N}\right)$ on peat have the potential to identify changes in past hydroclimate conditions. Hummock species are more influenced by rainwater/surface bog water than deeper bog water, and rain water has lower $\delta^{15} \mathrm{~N}$ values than bog water. Therefore, hummock species should have lower $\delta^{15} \mathrm{~N}$ values than 
hollow species $[16,61,62]$. During drier conditions, a lower water table will cause the plant to utilize more rain water, decreasing the $\delta^{15} \mathrm{~N}$ values [16].

The $\delta^{13} \mathrm{C}$ and $\delta^{15} \mathrm{~N}$ values from the Teringi record provide complementing perspectives of likely shifts in hydrologic conditions during the late Holocene. The $\delta^{13} \mathrm{C}$ values taken from bulk peat at Teringi show a slight step-wise increase through time, suggesting that conditions have become increasingly wetter. The $\delta^{15} \mathrm{~N}$ values in the core are all generally within range ( $-4 \%$ to $0 \%$ ) of typical Sphagnum mosses [16] and are more variable than the $\delta^{13} \mathrm{C}$ values. The $\delta^{15} \mathrm{~N}$ values were low from $\sim 4130$ to $3645 \mathrm{cal} \mathrm{yr} \mathrm{BP}$, suggesting drier conditions, followed by intermediate values until $2995 \mathrm{cal}$ yr BP. There was another shift to likely drier conditions from $\sim 2995$ to $\sim 2470 \mathrm{cal}$ yr BP. The $\delta^{15} \mathrm{~N}$ values suggest intermediate hydroclimate conditions until $\sim 955 \mathrm{cal}$ yr BP, followed by wetter conditions until 250 cal yr BP, and then values were intermediate again through the modern. Here, again, the actual response time for plant species to climate forcing is uncertain, but any shifts in $\delta^{15} \mathrm{~N}$ values probably lag any hydroclimate forcing by at least 2 centuries [45]. The results of the PCA also indicate that while there is a moderately strong relationship between water table fluctuations in Estonia and $\delta^{13} \mathrm{C}$ and $\delta^{15} \mathrm{~N}$ values at Teringi, multiple environmental variables likely also drove variations in these peatland systems through time (Figure 10 and Table 3). Likewise, the lack of correlation between $\% \mathrm{C}$ and $\% \mathrm{~N}$ with the available proxies for temperature and wetness suggests that these systems within the bog respond to complex interactions of multiple environmental variables.

\subsection{Carbon Accumulation Rates and Hydrologic Conditions}

Generally speaking, carbon accumulation rates for peatland systems vary largely as a function of bulk density and age-model calculations [41]. For Teringi, there are multiple possible calibrated ages for the uppermost radiocarbon sample; however, recalculating flux based on the maximum and minimum possible values (Table 1) resulted in no significant differences in the timing of shifts in the carbon accumulation record compared to the weighted mean modeled ages. Humification of peat (process of decomposing litter into humic substances) can also lead to higher bulk density and carbon flux rates; however, the $\mathrm{C}: \mathrm{N}$ values in the Teringi core exhibit only slight shifts through time, suggesting that there were no prolonged periods of organic matter decay during the late Holocene [63].

Bulk density is generally higher in sections of the Teringi core where S. fuscum is more dominant and lower in sections where the composition is more diverse. Compared to most of the core, the bulk density values are high from $~ 1860$ to $1790 \mathrm{cal} \mathrm{yr} \mathrm{BP}$, from $\sim 1670$ to $1500 \mathrm{cal} \mathrm{yr} \mathrm{BP}$, and again from 585 to $340 \mathrm{cal}$ yr BP. The bulk density values are lowest from $\sim 3350$ to $1860 \mathrm{cal}$ yr BP, low from $\sim 1790$ to $1675 \mathrm{cal}$ yr BP, and low again from $\sim 1500$ to 1295 cal yr BP. Otherwise, the remaining sections of core had intermediate values. Hummock species become more dominant under drier conditions while hollow species are more common when it is wetter [45], and hummock species have higher growth rates than hollow species [64]. Combined with the $\delta^{15} \mathrm{~N}$ and C:N data, these observations suggest that bulk density values in the Teringi Bog record are probably controlled more by changes in the species that are present than by decomposition. The results of the PCA suggest that bulk density and carbon accumulation values are generally low in sections of the core that represent dry periods and high during wetter periods while temperature played only a limited role (Figure 10).

\subsection{Climate Dynamics during the Late Holocene (4200 Cal Yr BP to Present)}

Broad-scale patterns of shifting mean-state climate conditions during the late Holocene in Estonia can be inferred from the Teringi Bog core data combined with marine and terrestrial paleoclimate records. The onset of Neoglaciation and declining Northern Hemisphere high-latitude summer insolation [65] likely led to an overall colder climate (Figure 9). Pollen records from Lakes Raigastvere in Estonia [66] and Tsoulbmajavri in Finland [44] indeed indicate a trend toward colder conditions in the northern Baltic region during the late Holocene. Lake sediment stable isotope records suggest that precipitation patterns 
and circulation dynamics were variable, but that there was also a trend of overall wetter conditions through the late Holocene [31,53]. Thus, the overall trend of higher $\delta^{13} \mathrm{C}$ values recorded at Teringi Bog suggests that a wetter climate seems to coincide with a broader pattern of colder and wetter conditions in the Baltic region.

The basal radiocarbon age from Teringi ( 4200 cal yr BP) is notable when compared to the timing and pattern of Holocene Northern Hemisphere climate change. The start of the late Holocene is defined as $4200 \mathrm{cal}$ yr BP [67] when there was a major shift in circulation dynamics and hydrologic balance across northern Europe at the onset of Neoglaciation and declining Northern Hemisphere high-latitude summer insolation [68]. It is unclear what lies below $\sim 530 \mathrm{~cm}$ depth at Teringi Bog, as the material below was impenetrable. This same impenetrable layer was present in a transect across the bog [46]. Interestingly, Männikjärve Bog in northeast Estonia has a basal radiocarbon age of $\sim 4360$ cal yr BP that similarly marks the initiation of ombrotrophic conditions [45]. We therefore suggest that the environmental conditions became conducive for Sphagnum growth in the center of both bogs sometime before $\sim 4200$ cal yr BP, possibly as a result of wetter and cooler conditions in the region compared to the middle Holocene, and that these conditions remained relatively cool and wet through the late Holocene.

Multi-centennial- to centennial-scale periods of hydroclimate variability in northern Europe likely affected peatland carbon dynamics. For example, changes in water table depth based on testate amoebae from Männikjärve Bog identify drier conditions in Estonia while carbon accumulation rates were low at Teringi Bog from $\sim 4200$ to 2470 cal yr BP (Figure 9). Carbon accumulation rates were then generally the highest at Teringi Bog (up to $\sim 80 \mathrm{~g} \mathrm{C} \mathrm{m}^{-2} \mathrm{yr}^{-1}$ ) from $\sim 2470$ to 1645 cal yr BP when the bulk of the proxy records suggest that it was wet and temperatures were intermediate. These carbon accumulation values are relatively high compared to much of Europe [41], and while it is presently unclear exactly why these values are higher, it might be because Sphagnum dominates throughout the core and it is remarkably well-preserved. The Teringi $\delta^{13} \mathrm{C}$ and $\delta^{15} \mathrm{~N}$ data, combined with other paleoclimate records from the region [69-73], suggest that hydroclimate conditions were likely intermediate to dry for several centuries prior to, and including the Medieval Climate Anomaly (MCA; 1000 to 700 cal yr BP), compared to earlier in the late Holocene (Figure 9). Similarly, carbon accumulation rates also appear to be low at Teringi from $\sim 1645$ to $\sim 585 \mathrm{cal}$ yr BP. The Little Ice Age (LIA) in northern Europe that followed is defined as a relatively cold period from $\sim 450$ to $100 \mathrm{cal}$ yr BP [74]. During the LIA, there was a shift to intermediate carbon accumulation rates compared to several centuries prior in the Teringi record that continued through present day (Figure 9). This suggests that colder and wetter LIA conditions were generally favorable for peat growth and carbon accumulation.

\subsection{Future Implications}

Future shifts in hydroclimate, water table dynamics, and/or temperature will impact the potential for Teringi Bog and other regional peatlands to capture and store carbon. The Baltic region will likely receive more precipitation and become $4-5{ }^{\circ} \mathrm{C}$ warmer during the next century [75-79]. However, there is a high degree of uncertainty in future model projections: down-scaled regional climate models (RCMs) forecast either no substantial change, or up to a $\sim 20 \%$ increase in precipitation for the Baltic States [80-82]. The uncertainties of these models stem largely from a lack of climate reconstructions extending beyond the instrumental period [83], and the current model ensembles simply do not accurately represent the full range of precipitation variability that exists across the Baltic States [84]. In a range of RCM simulations, the rate of evapotranspiration in regions south of the Baltic Sea will likely increase in the future [85], which should lead to overall drier conditions. Likewise, a range of long-term climate projections indicate that the Baltic region will likely experience a decrease in relative humidity as temperatures increase, even if there is an increase in precipitation amounts [86]. It is also possible that human impacts and changes in biodiversity might outpace any climatic influences, which could significantly alter the carbon dynamics of Baltic peatlands. Nevertheless, periods of the late Holocene when there 
were warmer and drier conditions, combined with lower carbon accumulation rates, might serve as analogues for future environmental conditions in Estonian peatlands.

\section{Conclusions}

The water balance and past carbon dynamics of Teringi Bog appear to be driven mostly by variations in humidity and precipitation followed by temperature changes. Analyses of stable isotopes $\left(\delta^{13} \mathrm{C}\right.$ and $\left.\delta^{15} \mathrm{~N}\right)$ measured on peat cores taken from the bog, combined with multiple proxy records from the region, suggest that there was a trend toward wetter conditions in Estonia during the late Holocene. Carbon accumulation rates were low from $\sim 4200$ to 2470 cal yr BP when it was generally warm and dry. Carbon accumulation rates were then higher at Teringi Bog from 2470 to 1645 cal yr BP when conditions were wetter and temperatures were intermediate. Several centuries leading up to and including the MCA had overall low carbon accumulation rates. The LIA was also a period of increased carbon accumulation when it was colder, suggesting that evaporation rates and/or decomposition was lower during that interval. At present, it is unclear if ombrotrophic peatlands will become sinks or sources of carbon emissions in the coming decades, and more detailed local-scale studies are needed in order to understand the fate of greenhouse gases in northern European wetlands. Nevertheless, the results presented here suggest that decreased precipitation amounts, lower relative humidity and/or higher temperatures will likely lead to a negative carbon balance for Teringi Bog.

Author Contributions: Conceptualization, methodology, supervision, investigation, formal analysis, project administration, writing — original draft preparation, and funding acquisition, N.D.S.; conceptualization, methodology, supervision, investigation, formal analysis, and writing-review and editing, E.S.K.; methodology, formal analysis, investigation, and writing-review and editing, K.H.; supervision, investigation, formal analysis, and writing-review and editing, J.T. and J.D.; investigation and writing-review and editing, M.E. and B.P.; investigation, M.B., M.E., C.F., A.F., R.G. and B.S.; All authors have read and agreed to the published version of the manuscript.

Funding: This project was funded by the U.S. National Science Foundation, International Research Experiences for Students (IRES) grant (OISE-1827135). Additional funding for this project was provided by the Research and Artistry grant program and Goldich funds from Northern Illinois University.

Data Availability Statement: The peat core data for this project are available at https:/ / www.ncdc. noaa.gov/paleo/study/34995 (accessed on 1 August 2021).

Acknowledgments: We thank Nicole LaDue, Luule Lauk, Hannes Saag, Sten Sarap, Evelin Stansell, Sheldon Turner, Tiit Vaasma, David Voorhees and the Paavel family. The Institute of Ecology at Tallinn University graciously hosted NDS for a sabbatical while this paper was written. This manuscript benefited greatly from comments by Martin Küttim and 2 anonymous reviewers.

Conflicts of Interest: The authors declare no conflict of interest.

\section{References}

1. Gorham, E. Northern Peatlands: Role in the Carbon Cycle and Probable Responses to Climatic Warming. Ecol. Appl. 1991, 1, 182-195. [CrossRef]

2. Turunen, J.; Tomppo, E.; Tolonen, K.; Reinikainen, A. Estimating carbon accumulation rates of undrained mires in Finlandapplication to boreal and subarctic regions. Holocene 2002, 12, 69-80. [CrossRef]

3. Yu, Z.; Loisel, J.; Brosseau, D.P.; Beilman, D.W.; Hunt, S.J. Global peatland dynamics since the Last Glacial Maximum. Geophys. Res. Lett. 2010, 37, L13402. [CrossRef]

4. Jobbágy, E.G.; Jackson, R.B. The vertical distribution of soil organic carbon and its relation to climate and vegetation. Ecol. Appl. 2000, 10, 423-436. [CrossRef]

5. Battle, M.; Bender, M.; Tans, P.P.; White, J.; Ellis, J.; Conway, T.; Francey, R. Global carbon sinks and their variability inferred from atmospheric $\mathrm{O}_{2}$ and $813 \mathrm{C}$. Science 2000, 287, 2467-2470. [CrossRef] [PubMed]

6. Grosse, G.; Harden, J.; Turetsky, M.; McGuire, A.D.; Camill, P.; Tarnocai, C.; Frolking, S.; Schuur, E.A.; Jorgenson, T.; Marchenko, S. Vulnerability of high-latitude soil organic carbon in North America to disturbance. J. Geophys. Res. Biogeosci. 2011, 116, G00K06. [CrossRef]

7. Turetsky, M.R.; Kane, E.S.; Harden, J.W.; Ottmar, R.D.; Manies, K.L.; Hoy, E.; Kasischke, E.S. Recent acceleration of biomass burning and carbon losses in Alaskan forests and peatlands. Nat. Geosci. 2011, 4, 27-31. [CrossRef] 
8. Davidson, E.A.; Janssens, I.A. Temperature sensitivity of soil carbon decomposition and feedbacks to climate change. Nature 2006, 440, 165-173. [CrossRef] [PubMed]

9. McGuire, A.; Hayes, D.J.; Kicklighter, D.W.; Manizza, M.; Zhuang, Q.; Chen, M.; Follows, M.J.; Gurney, K.; Mcclelland, J.W.; Melillo, J. An analysis of the carbon balance of the Arctic Basin from 1997 to 2006. Tellus B Chem. Phys. Meteorol. 2010, 62, 455-474. [CrossRef]

10. Jones, M.C.; Yu, Z. Rapid deglacial and early Holocene expansion of peatlands in Alaska. Proc. Natl. Acad. Sci. USA 2010, 107, 7347-7352. [CrossRef]

11. Frolking, S.; Roulet, N.T.; Tuittila, E.; Bubier, J.L.; Quillet, A.; Talbot, J.; Richard, P. A new model of Holocene peatland net primary production, decomposition, water balance, and peat accumulation. Earth Syst. Dyn. 2010, 1, 1-21. [CrossRef]

12. Rydin, H.; Jeglum, J.K. The Biology of Peatlands, 2nd ed.; Oxford University Press: Oxford, UK, 2013.

13. Clymo, R.; Bryant, C. Diffusion and mass flow of dissolved carbon dioxide, methane, and dissolved organic carbon in a 7-m deep raised peat bog. Geochim. Cosmochim. Acta 2008, 72, 2048-2066. [CrossRef]

14. Tfaily, M.M.; Wilson, R.M.; Cooper, W.T.; Kostka, J.E.; Hanson, P.; Chanton, J.P. Vertical Stratification of Peat Pore Water Dissolved Organic Matter Composition in a Peat Bog in Northern Minnesota. J. Geophys. Res. Biogeosci. 2018, 123, 479-494. [CrossRef]

15. Loisel, J.; Garneau, M.; Hélie, J.-F. Sphagnum $813 \mathrm{C}$ values as indicators of palaeohydrological changes in a peat bog. Holocene 2010, 20, 285-291. [CrossRef]

16. Stansell, N.D.; Klein, E.S.; Finkenbinder, M.S.; Fortney, C.S.; Dodd, J.P.; Terasmaa, J.; Nelson, D.B. A stable isotope record of Holocene precipitation dynamics in the Baltic region from Lake Nuudsaku, Estonia. Quat. Sci. Rev. 2017, 175, 73-84. [CrossRef]

17. Asada, T.; Warner, B.G.; Aravena, R. Nitrogen isotope signature variability in plant species from open peatland. Aquat. Bot. 2005, 82, 297-307. [CrossRef]

18. Laine, J.; Vasander, H. Ecology and vegetation gradients of peatlands. Peatl. Finl. 1996, 10, 20.

19. Hugelius, G.; Loisel, J.; Chadburn, S.; Jackson, R.B.; Jones, M.; MacDonald, G.; Marushchak, M.; Olefeldt, D.; Packalen, M.; Siewert, M.B.; et al. Large stocks of peatland carbon and nitrogen are vulnerable to permafrost thaw. Proc. Natl. Acad. Sci. USA 2020, 117, 20438-20446. [CrossRef] [PubMed]

20. Ives, S.L.; Sullivan, P.F.; Dial, R.; Berg, E.E.; Welker, J.M. $\mathrm{CO}_{2}$ exchange along a hydrologic gradient in the Kenai Lowlands, AK: Feedback implications of wetland drying and vegetation succession. Ecohydrology 2013, 6, 38-50. [CrossRef]

21. Punning, J.M.; Toots, M.; Vaikmäe, R. Oxygen-18 in Estonian Natural Waters. Isot. Isot. Environ. Health Stud. 1987, 23, 232-234. [CrossRef]

22. Klein, E.S.; Booth, R.K.; Yu, Z.; Mark, B.G.; Stansell, N.D. Hydrology-mediated differential response of carbon accumulation to late Holocene climate change at two peatlands in Southcentral Alaska. Quat. Sci. Rev. 2013, 64, 61-75. [CrossRef]

23. Berger, A.; Loutre, M.F. Insolation values for the climate of the last 10 million years. Quat. Sci. Rev. 1991, 10, 297-317. [CrossRef]

24. Paal, J. Rare and threatened plant communities of Estonia. Biodivers. Conserv. 1998, 7, 1027-1049. [CrossRef]

25. Kalm, V. Pleistocene chronostratigraphy in Estonia, southeastern sector of the Scandinavian glaciation. Quat. Sci. Rev. 2006, 25, 960-975. [CrossRef]

26. Masing, V.; Paal, J.; Kuresoo, A. Biodiversity of Estonian wetlands. Biodivers. Wetl. Assess. Funct. Conserv. 2000, 1, $259-279$.

27. Paal, J. Estonian mires. Mires—Sib. Tierra Del Fuego. Stapfia85 Zugleich Kat. Der OO. Landesmuseen Neue Ser. 2005, 35, 117-146.

28. Jaagus, J. The impact of climate change on the snow cover pattern in Estonia. Clim. Change 1997, 36, 65-77. [CrossRef]

29. Jaagus, J. Climatic changes in Estonia during the second half of the 20th century in relationship with changes in large-scale atmospheric circulation. Theor. Appl. Climatol. 2006, 83, 77-88. [CrossRef]

30. Bladé, I.; Liebmann, B.; Fortuny, D.; Oldenborgh, G. Observed and simulated impacts of the summer NAO in Europe: Implications for projected drying in the Mediterranean region. Clim. Dyn. 2012, 39, 709-727. [CrossRef]

31. Mätlik, O.; Post, P. Synoptic Weather Types That Have Caused Heavy Precipitation in Estonia in the Period 1961-2005. Est. J. Eng. 2008, 14, 195-208. [CrossRef]

32. Wassenaar, L.I.; Coplen, T.B.; Aggarwal, P.K. Approaches for Achieving Long-Term Accuracy and Precision of $\delta 18 \mathrm{O}$ and $\delta 2 \mathrm{H}$ for Waters Analyzed using Laser Absorption Spectrometers. Environ. Sci. Technol. 2014, 48, 1123-1131. [CrossRef] [PubMed]

33. Coplen, T.B. Guidelines and recommended terms for expression of stable-isotope-ratio and gas-ratio measurement results. Rapid Commun. Mass Spectrom. 2011, 25, 2538-2560. [CrossRef]

34. Reimer, P.J.; Austin, W.E.; Bard, E.; Bayliss, A.; Blackwell, P.G.; Ramsey, C.B.; Butzin, M.; Cheng, H.; Edwards, R.L.; Friedrich, M. The IntCal20 Northern Hemisphere radiocarbon age calibration curve (0-55 cal kBP). Radiocarbon 2020, 62, 725-757. [CrossRef]

35. Blaauw, M.; Christen, J.A. Flexible paleoclimate age-depth models using an autoregressive gamma process. Bayesian Anal. 2011, 6, 457-474. [CrossRef]

36. Laine, J.; Harju, P.; Timonen, T.; Laine, A.; Tuittila, E.-S.; Minkkinen, K.; Vasander, H. The Intricate Beauty of Sphagnum Mosses-A Finnish Guide to Identification; University of Helsinki, Department of Forest Ecology: Helsinki, Finland, 2009.

37. Loader, N.; McCarroll, D.; van der Knaap, W.O.; Robertson, I.; Gagen, M. Characterizing carbon isotopic variability in Sphagnum. Holocene 2007, 17, 403-410. [CrossRef]

38. Dean, W.E. Determination of carbonate and organic matter in calcareous sediments and sedimentary rocks by loss on ignition: Comparison with other methods. J. Sediment. Petrol. 1974, 44, 242-248.

39. Heiri, O.; Lotter, A.F.; Lemcke, G. Loss on ignition as a method for estimating organic and carbonate content in sediments: Reproducibility and comparability of results. J. Paleolimnol. 2001, 25, 101-110. [CrossRef] 
40. Boyle, J. A comparison of two methods for estimating the organic matter content of sediments. J. Paleolimnol. $2004,31,125-127$.

41. Loisel, J.; Yu, Z.; Beilman, D.W.; Camill, P.; Alm, J.; Amesbury, M.J.; Anderson, D.; Andersson, S.; Bochicchio, C.; Barber, K.; et al. A database and synthesis of northern peatland soil properties and Holocene carbon and nitrogen accumulation. Holocene 2014, 24, 1028-1042. [CrossRef]

42. Rodionov, S.N. A sequential algorithm for testing climate regime shifts. Geophys. Res. Lett. 2004, 31, L09204. [CrossRef]

43. Lê, S.; Josse, J.; Husson, F. FactoMineR: An R package for multivariate analysis. J. Stat. Softw. 2008, 25, 1-18. [CrossRef]

44. Seppä, H.; Birks, H.J.B. July mean temperature and annual precipitation trends during the Holocene in the Fennoscandian tree-line area: Pollen-based climate reconstructions. Holocene 2001, 11, 527-539. [CrossRef]

45. Sillasoo, U.; Mauquoy, D.; Blundell, A.; Charman, D.A.N.; Blaauw, M.; Daniell, J.R.G.; Toms, P.; Newberry, J.; Chambers, F.M.; Karofeld, E. Peat multi-proxy data from Männikjärve bog as indicators of late Holocene climate changes in Estonia. Boreas 2007, 36, 20-37. [CrossRef]

46. Hill, K. Late Holocene Climate Controls on Carbon Dynamics at Teringi Bog, Estonia; Northern Illinois University: DeKalb, IL, USA, 2016.

47. Ménot, G.; Burns, S.J. Carbon isotopes in ombrogenic peat bog plants as climatic indicators: Calibration from an altitudinal transect in Switzerland. Org. Geochem. 2001, 32, 233-245. [CrossRef]

48. Dansgaard, W. Stable isotopes in precipitation. Tellus 1964, 16, 436-468. [CrossRef]

49. Rozanski, K.; Araquás-Araquás, L.; Gonfiantini, R. Relation Between Long-Term Trends of Oxygen-18 Isotope Composition of Precipitation and Climate. Science 1992, 258, 981-985. [CrossRef]

50. Baldini, L.M.; McDermott, F.; Foley, A.M.; Baldini, J.U.L. Spatial variability in the European winter precipitation $\delta 18 \mathrm{O}-\mathrm{NAO}$ relationship: Implications for reconstructing NAO-mode climate variability in the Holocene. Geophys. Res. Lett. 2008, 35 , L04709. [CrossRef]

51. St Amour, N.A.; Hammarlund, D.; Edwards, T.W.; Wolfe, B.B. New insights into Holocene atmospheric circulation dynamics in central Scandinavia inferred from oxygen-isotope records of lake-sediment cellulose. Boreas 2010, 39, 770-782. [CrossRef]

52. Hammarlund, D.; Björck, S.; Buchardt, B.; Israelson, C.; Thomsen, C.T. Rapid hydrological changes during the Holocene revealed by stable isotope records of lacustrine carbonates from Lake Igelsjön, southern Sweden. Quat. Sci. Rev. 2003, 22, 353-370. [CrossRef]

53. Heikkilä, M.; Edwards, T.W.D.; Seppä, H.; Sonninen, E. Sediment isotope tracers from Lake Saarikko, Finland, and implications for Holocene hydroclimatology. Quat. Sci. Rev. 2010, 29, 2146-2160. [CrossRef]

54. Luken, J.O. Zonation of Sphagnum Mosses: Interactions among Shoot Growth, Growth Form, and Water Balance. Bryologist 1985, 88, 374-379. [CrossRef]

55. Robroek, B.J.M.; Limpens, J.; Breeuwer, A.; Schouten, M.G.C. Effects of water level and temperature on performance of four Sphagnum mosses. Plant Ecol. 2007, 190, 97-107. [CrossRef]

56. Hájek, T.; Beckett, R.P. Effect of water content components on desiccation and recovery in Sphagnum mosses. Ann. Bot. 2008, 101, 165-173. [CrossRef] [PubMed]

57. Payette, S. Late-Holocene development of subarctic ombrotrophic peatlands: Allogenic and autogenic succession. Ecology 1988, 69, 516-531. [CrossRef]

58. Rastogi, A.; Antala, M.; Gąbka, M.; Rosadziński, S.; Stróżecki, M.; Brestic, M.; Juszczak, R. Impact of warming and reduced precipitation on morphology and chlorophyll concentration in peat mosses (Sphagnum angustifolium and S. fallax). Sci. Rep. 2020, 10, 8592. [CrossRef]

59. Moschen, R.; Kühl, N.; Rehberger, I.; Lücke, A. Stable carbon and oxygen isotopes in sub-fossil Sphagnum: Assessment of their applicability for palaeoclimatology. Chem. Geol. 2009, 259, 262-272. [CrossRef]

60. Ménot-Combes, G.; Burns, S.J.; Leuenberger, M. Variations of 18O/16O in plants from temperate peat bogs (Switzerland): Implications for paleoclimatic studies. Earth Planet. Sci. Lett. 2002, 202, 419-434. [CrossRef]

61. Melillo, J.M.; Aber, J.D.; Linkins, A.E.; Ricca, A.; Fry, B.; Nadelhoffer, K.J. Carbon and nitrogen dynamics along the decay continuum: Plant litter to soil organic matter. Plant. Soil 1989, 115, 189-198. [CrossRef]

62. Malmer, N.; Svensson, G.; Wallén, B. Mass balance and nitrogen accumulation in hummocks on a South Swedish bog during the late Holocene. Ecography 1997, 20, 535-549. [CrossRef]

63. Kuhry, P.; Vitt, D.H. Fossil Carbon/Nitrogen Ratios as a Measure of Peat Decomposition. Ecology 1996, 77, 271-275. [CrossRef]

64. Ohlson, M.; Dahlberg, B. Rate of peat increment in hummock and lawn communities on Swedish mires during the last 150 years. Oikos 1991, 61, 369-378. [CrossRef]

65. Berger, A.L. Long-term variations of caloric insolation resulting from the Earth's orbital elements. Quat. Res. 1978, 9, 139-167. [CrossRef]

66. Seppä, H.; Poska, A. Holocene annual mean temperature changes in Estonia and their relationship to solar insolation and atmospheric circulation patterns. Quat. Res. 2004, 61, 22-31. [CrossRef]

67. Walker, M.J.C.; Berkelhammer, M.; Björck, S.; Cwynar, L.C.; Fisher, D.A.; Long, A.J.; Lowe, J.J.; Newnham, R.M.; Rasmussen, S.O.; Weiss, H. Formal subdivision of the Holocene Series/Epoch: A Discussion Paper by a Working Group of INTIMATE (Integration of ice-core, marine and terrestrial records) and the Subcommission on Quaternary Stratigraphy (International Commission on Stratigraphy). J. Quat. Sci. 2012, 27, 649-659. [CrossRef] 
68. Morley, A.; Rosenthal, Y.; deMenocal, P. Ocean-atmosphere climate shift during the mid-to-late Holocene transition. Earth Planet. Sci. Lett. 2014, 388, 18-26. [CrossRef]

69. Cowling, S.A.; Sykes, M.T.; Bradshaw, R.H.W. Palaeovegetation-model comparisons, climate change and tree succession in Scandinavia over the past 1500 years. J. Ecol. 2001, 89, 227-236. [CrossRef]

70. Poska, A.; Saarse, L.; Koppel, K.; Nielsen, A.B.; Avel, E.; Vassiljev, J.; Väli, V. The Verijärv area, South Estonia over the last millennium: A high resolution quantitative land-cover reconstruction based on pollen and historical data. Rev. Palaeobot. Palynol. 2014, 207, 5-17. [CrossRef]

71. Helama, S.; Meriläinen, J.; Tuomenvirta, H. Multicentennial megadrought in northern Europe coincided with a global El Niño-Southern Oscillation drought pattern during the Medieval Climate Anomaly. Geology 2009, 37, 175-178. [CrossRef]

72. Luoto, T.P.; Helama, S. Palaeoclimatological and palaeolimnological records from fossil midges and tree-rings: The role of the North Atlantic Oscillation in eastern Finland through the Medieval Climate Anomaly and Little Ice Age. Quat. Sci. Rev. 2010, 29, 2411-2423. [CrossRef]

73. Tiljander, M.I.A.; Saarnisto, M.; Ojala, A.E.K.; Saarinen, T. A 3000-year palaeoenvironmental record from annually laminated sediment of Lake Korttajarvi, central Finland. Boreas 2003, 32, 566-577. [CrossRef]

74. Tarand, A.; Nordli, P.Ø. The Tallinn Temperature Series Reconstructed Back Half a Millennium by Use of Proxy Data. In The Iceberg in the Mist: Northern Research in Pursuit of a "Little Ice Age"; Ogilvie, A.E.J., Jónsson, T., Eds.; Springer: Dordrecht, The Netherlands, 2001; pp. 189-199.

75. Stouffer, R.J.; Manabe, S. Response of a Coupled Ocean-Atmosphere Model to Increasing Atmospheric Carbon Dioxide: Sensitivity to the Rate of Increase. J. Clim. 1999, 12, 2224-2237. [CrossRef]

76. BACC. Assessment of Climate Change for the Baltic Sea Basin; Germany, 2008. Available online: https://link.springer.com/book/10 .1007/978-3-540-72786-6 (accessed on 1 August 2021).

77. EEA. European Environment Agency: National Adaptation Policy Processes in European Countries 2014. 2014. Available online: https:/ / www.eea.europa.eu/publications/national-adaptation-policy-processes (accessed on 1 August 2021).

78. IPCC. Climate Change 2014: Impacts, Adaptation, and Vulnerability. Part. B: Regional Aspects. Contribution of Working Group II to the Fifth Assessment Report of the Intergovernmental Panel on Climate Change; Barros, V.R.C.B., Field, D.J., Dokken, M.D., Mastrandrea, K.J., Mach., T.E., Bilir, M., Chatterjee, K.L., Ebi, Y.O., Estrada, R.C., Genova, B., et al., Eds.; Cambridge University Press: Cambridge, UK; New York, NY, USA, 2014.

79. Kont, A.; Jaagus, J.; Aunap, R. Climate change scenarios and the effect of sea-level rise for Estonia. Glob. Planet. Change 2003, 36, 1-15. [CrossRef]

80. Kauker, F.; Meier, H.E.M. Modeling decadal variability of the Baltic Sea: 1. Reconstructing atmospheric surface data for the period 1902-1998. J. Geophys. Res. Ocean. 2003, 108, 3267. [CrossRef]

81. Meier, H.E.M.; Kauker, F. Modeling decadal variability of the Baltic Sea: 2. Role of freshwater inflow and large-scale atmospheric circulation for salinity. J. Geophys. Res. Ocean. 2003, 108, 3368. [CrossRef]

82. Meier, H.E.M. Baltic Sea climate in the late twenty-first century: A dynamical downscaling approach using two global models and two emission scenarios. Clim. Dyn. 2006, 27, 39-68. [CrossRef]

83. Harrison, S.P.; Bartlein, P.J.; Izumi, K.; Li, G.; Annan, J.; Hargreaves, J.; Braconnot, P.; Kageyama, M. Evaluation of CMIP5 palaeo-simulations to improve climate projections. Nat. Clim. Change 2015, 5, 735-743. [CrossRef]

84. Rutgersson, A.; Jaagus, J.; Schenk, F.; Stendel, M. Observed changes and variability of atmospheric parameters in the Baltic Sea region during the last 200 years. Clim. Res. 2014, 61, 177-190. [CrossRef]

85. Graham, L.P. Climate Change Effects on River Flow to the Baltic Sea. AMBIO A J. Hum. Environ. 2004, 33, 235-241. [CrossRef]

86. Collins, M.; Knutti, R.; Arblaster, J.; Dufresne, J.-L.; Fichefet, T.; Friedlingstein, P.; Gao, X.; Gutowski, W.J.; Johns, T.; Krinner, G. Long-term climate change: Projections, commitments and irreversibility. In Climate Change 2013-The Physical Science Basis: Contribution of Working Group I to the Fifth Assessment Report of the Intergovernmental Panel on Climate Change; Cambridge University Press: Cambridge, UK, 2013; pp. 1029-1136. 